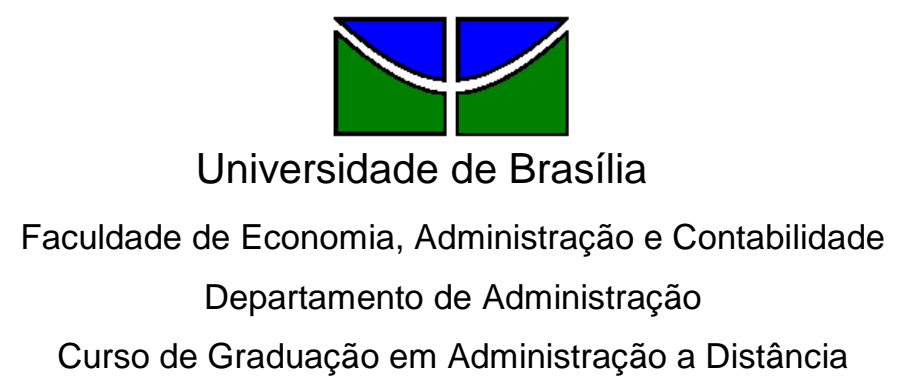

MARCELLO KATALINIC DUTRA

\title{
ESTUDO DE CASO SOBRE A IMPLANTAÇÃO DE UM SISTEMA DE APOIO À DECISÃO.
}

Brasília-DF 


\section{MARCELLO KATALINIC DUTRA}

\section{ESTUDO DE CASO SOBRE A IMPLANTAÇÃO DE UM SISTEMA DE APOIO À DECISÃO.}

Monografia apresentada a Universidade de Brasília (UnB) como requisito parcial para obtenção do grau de Bacharel em Administração.

Professor Orientador: Dr. Rildo Ribeiro dos Santos

Brasília - DF 
Dutra, Marcello Katalinic.

Estudo de caso sobre a implantação de um sistema de apoio à decisão./ Marcello Katalinic Dutra. - Brasília, 2010.

$97 \mathrm{f}$. : il.

Monografia (bacharelado) - Universidade de Brasília, Departamento de Administração - EaD, 2008.

Orientador: Prof. Dr. Rildo Ribeiro dos Santos, Departamento de Administração.

Estudo de caso sobre a implantação de um sistema de apoio à decisão. 


\title{
MARCELLO KATALINIC DUTRA
}

\section{ESTUDO DE CASO SOBRE A IMPLANTAÇÃO DE UM SISTEMA DE APOIO À DECISÃO.}

\begin{abstract}
A Comissão Examinadora, abaixo identificada, aprova o Trabalho de Conclusão do Curso de Administração da Universidade de Brasília do aluno
\end{abstract}

\section{Marcello Katalinic Dutra}

\author{
Dr. Rildo Ribeiro dos Santos \\ Professor-Orientador
}

Dr. Rildo Ribeiro dos Santos

Professor-Examinador
Esp. Viviane Moura Martins

Professora-Examinadora 
A Deus, por me abençoar e permitir a minha formatura em meu segundo curso superior na UnB. A minha querida esposa Eliane pela colaboração e paciência nos momentos de ausência.

Aos meus queridos filhos Victor e Juliana pelo amor que sempre me deram. 
AGRADECIMENTOS

Aos professores e tutores que acreditaram no curso de educação a distância. 
"Não sabendo que era impossível, foi lá e fez." JEAN COCTEAU 


\section{RESUMO}

No início do século 21 vemos grandes mudanças na forma de gerenciamento das empresas que passaram a contar fortemente com apoio de computadores para a tomada de decisão. Cada vez mais os administradores buscam apoio nos dados gerados pelos sistemas da empresa e nos dados presentes na Web. A grande quantidade de dados gerados e armazenados passou a ser de difícil interpretação sem o apoio de computadores e o principal problema passou a ser a escolha, dentre os dados disponíveis, daqueles relevantes. Nos dias de hoje, as empresas podem contar facilmente com Intranets e a Internet para fornecer aplicativos de análise de desempenho que são de grande valor aos administradores responsáveis pelas decisões nas empresas. Nesse contexto, esse estudo investigou nessa pesquisa a contribuição das ferramentas da tecnologia da informação, especificamente as de Business Intelligence (BI) que permitem o armazenamento, consulta, cruzamento, agrupamento e extração de dados, com o uso de técnicas, métodos e ferramentas a fim de transformá-los em informações úteis e auxiliar no processo decisório. O estudo foi conduzido por meio de pesquisa de campo, especialmente de um estudo de caso, em que o assunto pôde ser analisado em detalhes. Para tanto, fez-se uma entrevista diagnóstica e aplicou-se um questionário, orientadas por um roteiro previamente elaborado, bem como foram analisados documentos internos, registros em arquivos e observação direta como fonte de evidências. Os resultados obtidos mostraram que o sistema foi bem aceito na organização, porém sua utilização ainda é feita de forma modesta, sobretudo pela falta de treinamento e pelos problemas da cultura organizacional. Conclui-se pela importância da utilização de sistemas de apoio à decisão no gerenciamento dos dados e informações.

Palavras-chave: 1. Processo decisório 2. Sistema de apoio a decisão. 3. Dados e Informações 4. Sistemas de Informação 5. Business Intelligence 


\section{LISTA DE FIGURAS}

Figura 3.1 Relacionamento das Tabelas e Integridades Referenciais..................... 38

Figura 4.1.1 Percentagens de Características da Tarefa - Consolidado - ................ 47

Figura 4.1.2 Percentagens de Experiência com a Ferramenta - Consolidado -.......... 48

Figura 4.1.3 Percentagens de Facilidade de Uso Percebida - Consolidado -............ 48

Figura 4.1.4 Percentagens de Funcionalidade da Ferramenta - Consolidado -.......... 49



Figura 4.1.6 Percentagens de Uso Atual - Consolidado $-\ldots \ldots \ldots \ldots \ldots \ldots \ldots \ldots \ldots \ldots \ldots \ldots . . . . . . . . . . \ldots \ldots$

Figura 4.1.7 Percentagens de Utilidade Percebida - Consolidado -........................ 51

Figura 4.2.1 Percentagens de Características da Tarefa - Presidência - ................. 52

Figura 4.2.2 Percentagens de Experiência com a Ferramenta - Presidência -.......... 52

Figura 4.2.3 Percentagens de Facilidade de Uso Percebida - Presidência -............. 54

Figura 4.2.4 Percentagens de Funcionalidade da Ferramenta - Presidência -........... 54

Figura 4.2.5 Percentagens de Intenção de Usar a TI - Presidência -........................ 55

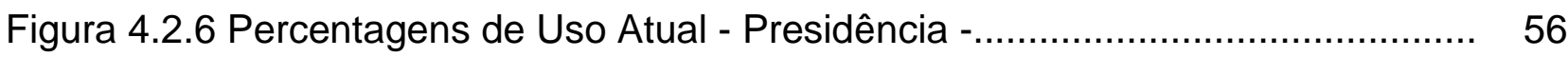

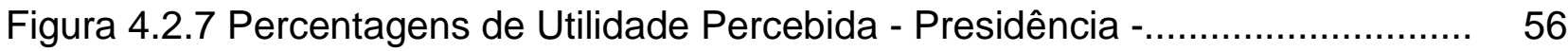

Figura 4.3.1 Percentagens de Características da Tarefa - Diretoria - .................... 58

Figura 4.3.2 Percentagens de Experiência com a Ferramenta - Diretoria -............... 58

Figura 4.3.3 Percentagens de Facilidade de Uso Percebida - Diretoria -................. 59

Figura 4.3.4 Percentagens de Funcionalidade da Ferramenta - Diretoria -.............. 60

Figura 4.3.5 Percentagens de Intenção de Usar a TI - Diretoria $-\ldots \ldots \ldots \ldots \ldots \ldots \ldots \ldots \ldots \ldots . . . \ldots \ldots$

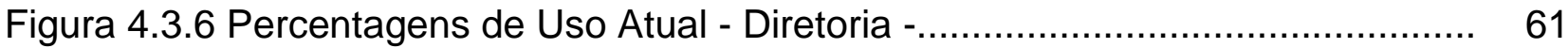

Figura 4.3.7 Percentagens de Utilidade Percebida - Diretoria $-\ldots \ldots \ldots \ldots \ldots \ldots \ldots \ldots \ldots \ldots . . \ldots 2$ 
Figura 4.4.1 Percentagens de Características da Tarefa - Empregados 63

Figura 4.4.2 Percentagens de Experiência com a Ferramenta - Empregados 64

Figura 4.4.3 Percentagens de Facilidade de Uso Percebida - Empregados 64

Figura 4.4.4 Percentagens de Funcionalidade da Ferramenta - Empregados 65

Figura 4.4.5 Percentagens de Intenção de Usar a TI - Empregados 66

Figura 4.4.6 Percentagens de Uso Atual - Empregados 66

Figura 4.4.7 Percentagens de Utilidade Percebida - Empregados - 


\section{LISTA DE TABELAS}

Tabela 3.1 Categorias e Dimensões de TAM e TTF.

Tabela 4.1 Visão das percentagens de aplicações e das notas atribuídas às respostas dos parâmetros TAM e TTF Instituição Beta - CONSOLIDADO -, Brasília - D.F., 2010

Tabela 4.2 Visão das percentagens de aplicações e das notas atribuídas às respostas dos parâmetros TAM e TTF Instituição Beta - PRESIDÊNCIA -, Brasília D.F., 2010

Tabela 4.3 Visão das percentagens de aplicações e das notas atribuídas às respostas dos parâmetros TAM e TTF Instituição Beta - DIRETORIA -, Brasília D.F., 2010

Tabela 4.4 Visão das percentagens de aplicações e das notas atribuídas às respostas dos parâmetros TAM e TTF Instituição Beta - EMPREGADOS -, Brasília - D.F., 2010

Tabela 4.5 Descrição geral das percentagens de aplicações e das notas atribuídas às respostas dos elementos do Sistema de Apoio à Decisão (SAD) instituição Beta, Brasília - D.F., 20010 


\section{LISTA DE ABREVIATURAS E SIGLAS}

$\mathrm{BI}$ - Business Intelligence

BPM - Business performance management

$\mathrm{Cl}$ - Competitive Intelligence

DW - Data Warehouse

DM - Data Mart

KDD - Knowledge Data Base Discovery

ROI - Return Over Investiment

SAD - Sistema de Apoio a Decisão

SADG - Sistema de Apoio à Decisão em Grupo

SAE - Sistema de Apoio ao Executivo

SIG - Sistema de Informações Gerenciais

SI - Sistemas de Informação

SGBD - Sistema de Gerenciamento de Banco de Dados

SGDBR - Sistema de Gerenciamento de Banco de Dados Relacional

TAM - Technology Acceptance Model

TI - Tecnologia da Informação

TRA - Theory of Reasoned Action

TTF - Task Technology Fit 


\section{SUMÁRIO}

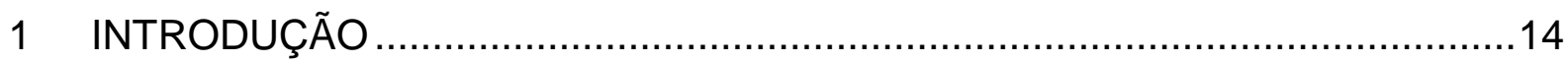

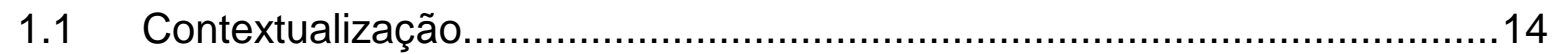

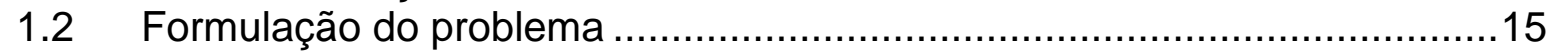

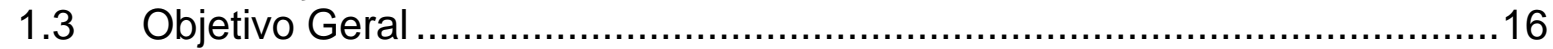

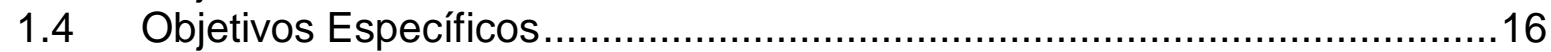

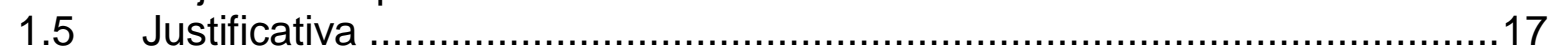

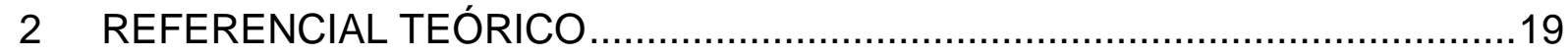

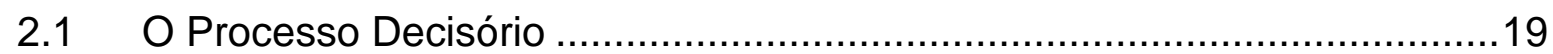

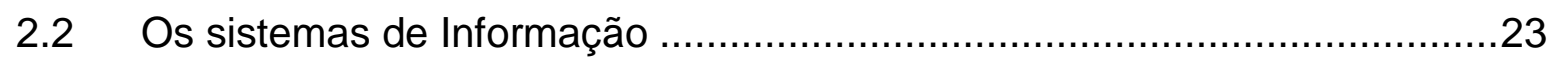

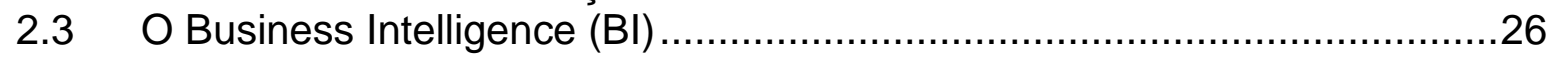

2.4 O Gerenciamento dos Dados na Tomada de Decisão...............................28

2.4.1 O Data Warehouse (DW) ...................................................................

2.4.2 Processamento Analítico Online (OLAP) .........................................30

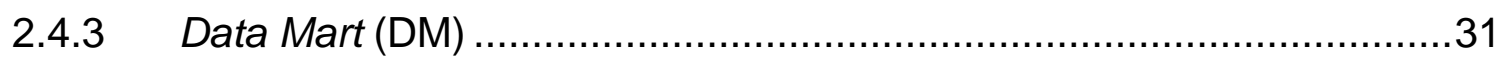



2.4.5 Business Performance Management (BPM) ...................................32

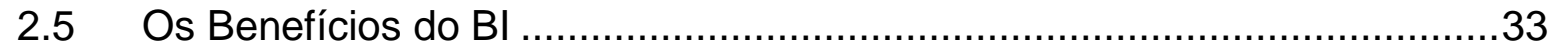

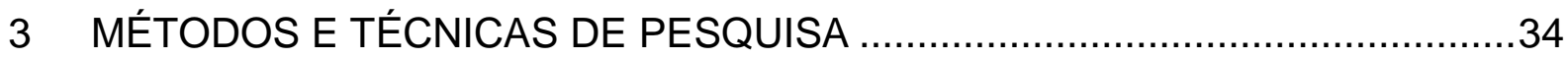

3.1 Tipo e Descrição Geral da Pesquisa......................................................34



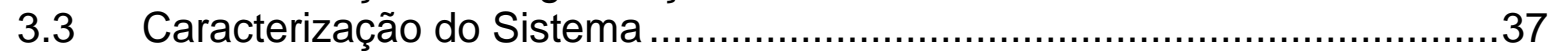

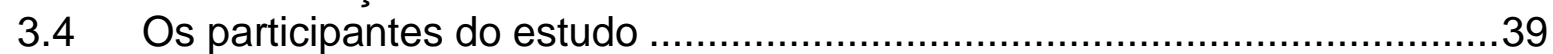

3.5 Caracterização do instrumento de pesquisa .........................................40

3.6 Procedimento de coleta e de análise de dados ....................................42

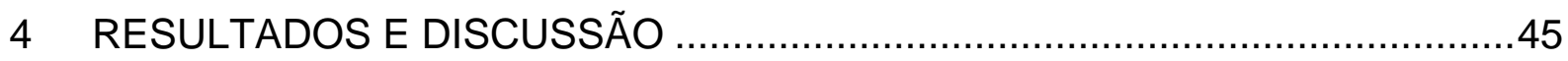

4.1 Análise das Contribuições dos Usuários do Sistema sob a Ótica dos

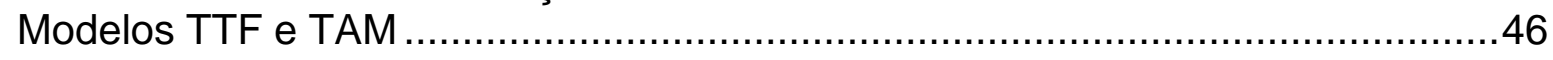

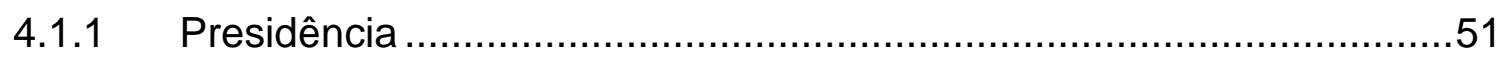

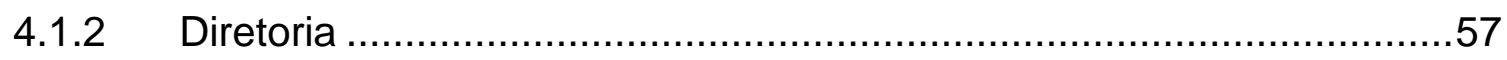

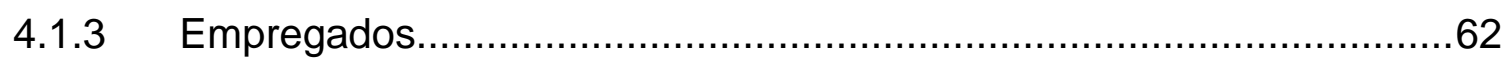

4.2 Análise das Contribuições dos Usuários do Sistema sob a Ótica das



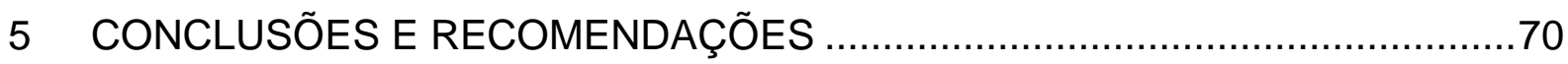

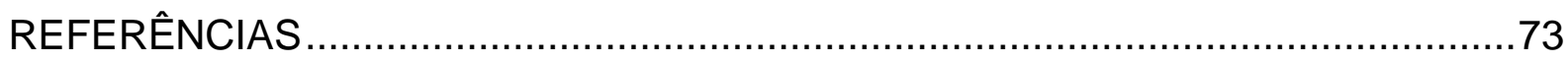


ANEXOS

.75

Anexo A - Organograma da Empresa Beta .76

APÊNDICES. 78

Apêndice A - Pesquisa Quantitativa 


\section{INTRODUÇÃO}

\subsection{Contextualização}

O ambiente de negócios no qual as empresas operam atualmente está se tornando cada vez mais complexo e mutante, a cada dia ocorre expansão do horizonte e aumento no volume de dados operacionais (BISPO, 1998). Os vários dados obtidos dos sistemas operacionais da instituição acabam por tornarem-se um empecilho pela dificuldade de armazenamento e organização. Muitas vezes os dados são desprezados, o que pode privar a empresa de manter e construir a sua inteligência corporativa. Esses dados poderiam ser armazenados para, por exemplo, construir séries históricas que auxiliariam nas tomadas de decisão. Os dados gerados que deveriam servir de apoio à tomada de decisão em nível tático e estratégico muitas vezes são apenas acumulados e armazenados de forma desorganizada (GOLFARELLI, 2004). Em poucos casos são observados gestores que baseiam seus atos em conhecimentos empíricos. Na maioria das vezes as decisões são tomadas apenas em função do instinto adquirido no desempenho da função ao longo dos anos. Dessa forma, as constantes mudanças no mundo corporativo e globalizado leva os gestores a sentirem-se fortemente pressionados a responder com celeridade suas decisões, ao mesmo tempo em que sentem a necessidade de encontrar maneiras inovadoras, com algum tipo de apoio computadorizado, no gerenciamento dos dados da empresa de forma a responder, se possível, ao mesmo tempo em que as ocorrências acontecem (REGINATO et al., 2007).

Nesse contexto, e como forma de armazenar, organizar e disponibilizar as informações surge o Data Warehouse (DW) que é um grande armazém de dados não concorrencial ao sistema mestre da instituição (INMON, 1997). O DW atende as necessidades gerenciais de informações e dá suporte às tomadas de decisão, possibilitando cruzamento dos dados, e utilização de Técnicas de Processamento Analítico On-line (OLAP), que fazem a extração de informações de um banco de 
dados, de forma multidimensional, em busca de variáveis relevantes e úteis para a organização. O DW é também um repositório de dados atuais e históricos de possível interesse aos gerentes de toda a organização. Seus dados são estruturados de modo a estarem disponíveis em um formato pronto para as atividades de processamento analítico. Sendo assim, o DW é uma coleção de dados orientados por assunto, integrados, variáveis no tempo e não-voláteis, que proporciona suporte ao processo de tomada de decisões da gerência (TURBAN et al., 2009). Os Data Marts (DM) são pequenos bancos de dados setoriais que integram o banco de dados principal da empresa e se concentra por assunto ou departamento específico. Ele é um subconjunto do Data Warehouse, que normalmente consiste em uma única área temática (TURBAN et al., 2009). O Data Mining (DM) é o processo de extração das informações visando a montagem de uma inteligência negocial que permite a identificação e análise das informações contidas no banco de dados, utilizando técnicas sofisticadas de procura, como algoritmos de inteligência artificial e procedimentos estatísticos avançados (INMON, 1997).

A implementação dessas ferramentas, além de ser importante diferencial estratégico, dá apoio aos gestores que passam a contar com informações interativas no processo de tomada de decisão (INMON, 1997). As consultas multidimensionais proporcionam um novo ângulo na forma de enxergar os dados armazenados, possibilitando realizar levantamentos estatísticos e emitir relatórios em vários formatos, permitindo assim avaliar múltiplas decisões aos problemas levantados com base em informações e não em suposições. Esse novo formato deixa as informações disponíveis aos gestores no momento em que eles necessitarem das mesmas, conferindo a inteligência de negócio, ou Business Intelligence.

\subsection{Formulação do problema}

A Partir do cenário descrito na contextualização deste trabalho, propõe-se investigar algumas das contribuições após a implantação de Business Intelligence (BI), ou Sistema de Apoio a Decisão (SAD), (FORTULAN, 2005) em uma instituição tradicional da capital federal. A instituição em questão, aqui identificada como Beta, 
aproveitou os dados existentes em vários setores, como contabilidade, financeiro e departamento de gestão de pessoas, para construir um DW. A partir dos registros contábeis e financeiros, bem como de dados do funcionalismo pré-existentes, a instituição organizou um banco de dados com o objetivo de suprir a gerência institucional com as informações por ela demandadas. O banco de dados foi criado a partir da utilização de ferramentas de Data Warehouse, Data Marts e Data Mining (INMON, 1997).

Verificando a dificuldade prévia da instituição foi formulada a seguinte questão: "Em que medida a implantação de um Sistema de Apoio à Decisão, baseado em Data Warehouse, pode contribuir com o processo de tomada de decisão dos gestores de uma organização?"

\subsection{Objetivo Geral}

Verificar como a implantação de ferramentas de Business Intelligence (BI), ou Sistema de Apoio a Decisão (SAD), contribuíram no processo de tomada de decisões da Instituição Beta.

\subsection{Objetivos Específicos}

$\checkmark$ Discorrer sobre processo decisório e sua relação com sistemas de apoio à decisão;

$\checkmark$ Identificar as ferramentas de soluções de tecnologia da informação utilizadas pela instituição Beta;

$\checkmark$ Mostrar a aplicabilidade dos conceitos Business Intelligence e Data Warehouse no processo de tomada de decisão na instituição Beta; 
$\checkmark$ Descrever a gestão e os benefícios dos sistemas de tomada de decisão apoiados em tecnologia da informação na instituição Beta.

\subsection{Justificativa}

Todos os dias as organizações se encontram diante de problemas de decisão. Esses problemas são bem mais amplos do que aqueles de um simples indivíduo, na medida em que o grau de complexidade das organizações é bem superior e envolve riscos e incertezas, necessitando do envolvimento e opinião de muitas pessoas em diversos níveis funcionais. Em uma organização o processo de decisão deve ser estruturado de modo formal, detalhado, consistente e transparente (SHIMIZU, 2006).

Laudon (2007) cita que a tomada de decisão nas empresas costumava ser limitada à diretoria. Hoje verifica-se que em todos os níveis da organização as pessoas tomam decisões. Os funcionários de níveis mais baixos também são responsáveis por alguma decisão, principalmente devido à farta disponibilidade de informações para os níveis mais elementares da empresa. Para cada um desses níveis existe uma necessidade específica de informação para apoiar as suas decisões e, muitas vezes, diferentes das necessárias de outros setores.

No mundo moderno, repleto de fonte de informações, aparece um novo problema para alta gerência das empresas, não apenas ter acesso rápido, ágil e confiável às informações, mas escolher dentre as opções disponíveis aquelas que dêem suporte às decisões, ou seja, as informações corretas e úteis, aquelas que aumentam a qualidade, a produtividade e a competitividade. Com o advento e popularização da tecnologia computacional, as empresas logo aumentaram e modernizaram o seu parque tecnológico a fim de suprirem com informações confiáveis e tempestivas a alta gerência. Para atingir esse objetivo, a tecnologia da informação passou a ser a principal ferramenta de apoio à tomada de decisão, na 
medida em que fornece as principais informações que serão usadas na elaboração de seu plano estratégico (REZENDE, 2002).

Nesse cenário, aparece o Business Intelligence com suas ferramentas que aproveitam os componentes desenvolvidos e instalados nos departamentos para ajudar as empresas a fazerem bom uso de seu investimento em Tecnologia da Informação, bem como a utilizarem os valiosos dados armazenados em sistemas legados e transacionais (TURBAN et al., 2009). Os administradores, por sua vez, passam a contar com o Data Warehousing e os modernos softwares de banco de dados relacionais, como o Access ${ }^{\mathrm{TM}}$ e as modernas planilhas de cálculo, como o Excel $^{\mathrm{TM}}$ que são largamente utilizados por terem interface bastante amigável para 0 usuário. 


\section{REFERENCIAL TEÓRICO}

\subsection{O Processo Decisório}

Quanto mais conhecimento e mais dados são gerados, disponibilizados e armazenados, mais complexos vão se tornando os sistemas gerenciais, as empresas e a sociedade. Para Drucker (2002), a revolução da informação, após o aparecimento dos primeiros computadores na década de 40 do século passado, não se deu na forma da apresentação da informação, mas apenas transformou processos gerenciais que já existiam. As decisões tampouco mudaram em sua maneira de serem tomadas, mas a revolução da informação rotinizou processos tradicionais em um grande número de áreas (DRUCKER, 2002). Os modernos conceitos administrativos, os novos programas computacionais e a Internet estão tornando o ambiente das empresas cada vez mais complexo. Os administradores responsáveis por tomar decisões nas empresas obtêm e analisam a todo momento informações que os levarão às decisões necessárias para a boa gestão e que garantirão a perenidade do negócio. Para Drucker (2006), os executivos concentram-se no que é importante, procurando localizar o que é invariável em uma situação, pensar no que é estratégico e genérico ao invés de resolver problemas. Aponta também que as decisões são julgamentos que envolvem risco e que devem obedecer a uma seqüência de etapas, descritas a seguir:

$\checkmark$ Classificação do problema - problema genérico, excepcional ou primeira manifestação;

$\checkmark$ Definição do problema - saber com que se esta lidando;

$\checkmark$ Especificação da resposta ao problema - definição das condições limites; 
$\checkmark$ Decisão do que é certo ao invés do que é aceitável - de modo que atenda às condições-limite. O que irá satisfazer plenamente às especificações antes que se dê atenção a conciliações, adaptações e concessões necessárias na tomada de decisão aceitável;

$\checkmark$ Incorporação à própria decisão a ação, para que ela seja cumprida - definir como deve ser o compromisso com a ação e estabelecer quem deverá ter conhecimento dele;

$\checkmark$ Testar a validade e a eficácia da decisão em relação ao verdadeiro rumo dos acontecimentos - observar como a decisão está sendo cumprida e se há pressupostos para que ela seja considerada apropriada ou se é obsoleta.

Muitos são os novos fatores envolvidos no cotidiano da alta e média administração. Hoje, raramente vemos grandes ou médias empresas que têm apenas o seu executivo principal como centro do processo decisório como era nos anos 60 do século passado. Houve aumento da produção, especialização e aumento da velocidade do processo de forma geral (PEREIRA \& FONSECA, 1997). A procura voraz por informações passou a fazer parte da estratégia corporativa.

O aumento na velocidade dos negócios levou a uma mudança global nas organizações e na postura da tomada de decisões estratégicas. As mudanças ocorreram, desde a estrutura, até o marketing. Para Kotler (2000) o ambiente da empresa está mudando a um ritmo cada vez mais acelerado e as necessidades de informação de mercado em tempo real para o processo decisório é maior do que em qualquer outra época. A competição entre as empresas se acirrou sobremaneira nessas últimas duas décadas, os mercados ficaram mais dinâmicos e forçaram os administradores a tomarem decisões mais rapidamente. $\mathrm{Na}$ outra ponta, os acionistas também colocaram mais pressão para que os lucros fossem aumentados, o que provocou um constante desafio nas empresas no sentido de se trabalhar sempre com criatividade e eficiência. Considerando esses aspectos, bem como os 
interesses políticos e econômicos, verifica-se a necessidade de proporcionar um bom suporte ao processo decisório para que o sucesso nos negócios seja atingido. Os administradores agora têm que tomar as suas decisões com base nas análises de todas as alternativas possíveis de forma a encontrar a escolha mais viável. Nesse ambiente, torna-se indispensável a utilização de suporte computacional para obtenção e análise das informações necessárias. O método de escolha da melhor alternativa deve ser confiável e testado de forma que as decisões empresariais sejam fundamentadas em uma base de dados e fatos comprovados e com a máxima certeza de que o resultado esperado será atingido (KOTLER, 2000).

Shimizu (2006) descreve os tipos de problemas e níveis de decisão apontando que, dada a simplicidade imposta pela racionalidade limitada, os problemas e métodos de decisão precisam ser classificados e analisados em detalhe, e sob o ponto de vista da tomada de decisão, os problemas podem ser classificados em três categorias, a saber:

- Problemas estruturados - ou bem definidos. São considerados como tal aqueles em que sua definição e fases de operação para chegar aos resultados desejados estejam bem esclarecidas e sua execução rotineira é sempre possível;

- Problemas semi-estruturados - são aqueles com operações bem conhecidas, mas que contêm algum fator ou critério variável que pode influir no resultado;

- Problemas não estruturados - são aqueles que, tanto os cenários, como os critérios de decisão, não estão fixados ou conhecidos anteriormente.

Para Laudon (2007) existem quatro tipos de sistema que apóiam a decisão, que são:

- Sistemas de informações gerenciais (SIG) - fornecem resumos e relatórios rotineiros com dados em nível de transações gerenciais para a gerência de nível operacional e médio, oferecendo respostas a problemas de decisão estruturada e semi-estruturada; 
- Sistemas de apoio à decisão (SAD) - fornecem ferramentas ou modelos analíticos para analisar grandes quantidades de dados e fazer consultas interativas de apoio aos gerentes de nível médio que enfrentam situações de decisão semi-estruturada;

- Sistema de apoio ao executivo (SAE) - fornecem à gerência sênior, normalmente envolvidas em decisões são estruturadas, informações externas, como notícias do mercado, tendências setoriais e resumos de alto nível quanto ao desempenho da empresa;

- Sistemas de apoio à decisão em grupo (SADG) - são sistemas especializados que oferecem um ambiente eletrônico onde os gerentes e equipes podem coletivamente tomar decisões e formular soluções para problemas não estruturados e semi-estruturados.

Em relação aos estágios no processo de decisão, Laudon (2007) observa que existem quatro estágios no processo:

- Inteligência - "consiste em descobrir, identificar e entender os problemas que estão ocorrendo na organização - por que existe um problema, onde ele está e qual o seu efeito" (LAUDON, 2007, p 305);

- Concepção - envolve a identificação e investigação das várias soluções possíveis para o problema;

- Seleção - que consiste em escolher uma das alternativas de solução, e;

- Implementação da solução - fase em que a alternativa escolhida deve funcionar e a sua monitoração deve apontar a medida da solução.

Não obstante aos vários processos a que a tomada de decisão está sujeita, Laudon (2007) aponta que a decisão pode ser melhorada por técnicas inteligentes, que consistem em sistemas especialistas, raciocínio baseado em casos, algoritmos genéricos, redes neurais, lógica difusa e agentes inteligentes, e sistemas de gestão 
do conhecimento. As tecnologias descritas ajudam os administradores responsáveis pelas decisões porque descobrem padrões e comportamentos em grandes quantidades de dados e geram soluções para problemas grandes e complexos demais para serem resolvidos pelo raciocínio humano.

\subsection{Os sistemas de Informação}

Sistema de informação "pode ser qualquer combinação organizada de pessoas, hardware, software, redes de comunicação, recurso de dados de políticas e procedimentos que armazenam, restauram, transformam e disseminam informações em uma organização" (O'BRIEN, 2007, p 4). Em outra definição encontramos o sistema de informação descrito como sendo "[...] um conjunto de componentes inter-relacionados que coletam, processam, armazenam e distribuem informações destinadas a apoiar a tomada de decisão, a coordenação e o controle de uma organização" (LAUDON, 2007, p. 9). Nesse cenário, sistema de informação descreve todos os componente e recursos necessários para entregar à organização a sua informação e suas funções.

Para O’Brien (2007) as aplicações de sistemas de informação podem ser classificadas de vários modos diferentes, como, por exemplo, sistemas operacionais e sistema de informação gerencial. Os operacionais produzem grande quantidade e variedade de resultados de informação utilizados internamente ou não nas organizações. No entanto, não apresentam facilidade de uso, especialmente em nível gerencial. Quanto aos sistemas gerenciais, são mais voltados em informar e dar suporte eficaz à tomada de decisão, fornecendo relatórios e telas a gerentes e profissionais ligados ao negócio. Os sistemas mais especializados dão suporte direto, normalmente por meio de computadores, aos gerentes durante o processo de tomada de decisão.

Resumidamente, O'Brien (2007, p. 14) define os sistemas em dois segmentos, quais sejam: 
De apoio operacional,

- Sistemas de processamento de transações, processa os dados resultantes das transações de negócios, atualiza bancos de dados operacionais e produz documentos de negócios;

- Sistemas de controle de processos, monitora o processo industrial;

- Sistema de colaboração empresarial que apóia a comunicação e colabora com as equipes e grupos de trabalho.

De apoio gerencial,

- Sistemas de informações gerenciais, fornece a informação na forma de relatórios e telas pré-especificadas para apoiar a tomada de decisão de negócios;

- Sistemas de suporte de decisão, provê suporte ad hoc interativo para os processos de tomada de decisão de gerentes e outros profissionais de negócios;

- Sistemas de informação executiva, fornece informação fundamental de fontes adaptadas às necessidades de informação dos executivos.

Mas o que torna os sistemas tão essenciais para as organizações e por que se investe tanto em tecnologia e sistemas de informação? Laudon (2007, p.6) destaca que as empresas têm a intenção de alcançar seis objetivos organizacionais destacados a seguir:

$>$ Excelência operacional - na busca de constante melhoramento da eficiência de suas operações, os administradores utilizam-se de tecnologia e sistemas de informação como ferramentas para atingir altos níveis de produtividade nas operações, especialmente quando combinadas com as mudanças no comportamento da administração e nas práticas de negócios;

$>$ Novos produtos, serviços e modelos de negócio - as tecnologias e os sistemas de informação são a principal ferramenta de que as 
empresas dispõem para criar novos produtos e serviços e modelos de negócios novos. Um modelo de negócio descreve como a empresa produz, entrega e vende um produto ou serviço a fim de obter lucros.

Relacionamento mais estreito com clientes e fornecedores utilização inteligente das tecnologias e dos sistemas de forma a identificar e disponibilizar, dentre as várias opções, aquelas escolhidas pelos clientes;

> Melhor tomada de decisões - utilização correta dos recursos tecnológicos de forma a reduzir custos e prover os administradores com informações úteis e tempestivas para tomar as decisões abalizadas em informações corretas;

Vantagem competitiva - esse objetivo é alcançado como conseqüência do atingimento dos outros relacionados acima. É a forma de fazer as coisas melhores que os concorrentes, despendendo menos recursos para obter produtos superiores e respondendo clientes e fornecedores em tempo real;

Sobrevivência - é outro motivo porque as empresas investem em sistemas e tecnologias de informação, eles passaram a ser imprescindíveis à prática dos negócios.

Os sistemas de informação, portanto, auxiliam no processo de identificação das informações e seu compartilhamento interno, nos vários departamentos, ou externo à organização, como fornecedores, clientes acionistas, órgãos reguladores e parceiros. Sendo uma organização estruturada formalmente e complexa, com finalidade de obter lucro ou não, as empresas possuem especialidades, como, por exemplo, finanças, contabilidade, recursos humanos, manufatura e produção, e vendas e marketing. Além disso, existe a estrutura de comando que divide as organizações em níveis, como, por exemplo, alta gerência, média gerência e baixa gerência. As empresas ainda precisam reagir ao ambiente a que estão expostas e responder às alterações políticas e às mudanças da economia de forma geral e acompanhar as tendências tecnológicas. Em cada um desses pontos identificados 
da organização aparecem os dados, os registros e as informações advindas dos setores. Nesse aspecto, verifica-se uma grande variedade de sistemas disponíveis capazes de auxiliar os administradores na função de analisar os dados e as informações, permitindo a simulação de cenários, cruzamento de informações e emissão de relatórios customizados. O correto estudo das informações disponibiliza alternativas de ações, com menor exposição ao risco indicando ao gestor a melhor escolha dentre as várias disponíveis e em conformidade com a situação apresentada.

\subsection{O Business Intelligence (BI)}

Os administradores modernos, de alguma forma, se acostumaram a tomar decisões baseados em números emitidos em relatórios, mas sempre de difícil manuseio e classificação. Até os anos 80 do século $\mathrm{XX}$, era comum observar nas empresas pilhas de relatórios em cima das mesas. Conforme análise de Ferauche (2006), os referidos relatórios não apresentavam facilidades de análise e eram previamente formatados segundo determinadas especificações que não se conseguia mudar facilmente. $O$ autor ainda refere que era comum a demanda por relatórios customizados que atendessem às necessidades de cada setor, o que poderia levar dias até meses para sua execução. Por exemplo, se houvesse a necessidade de ordenar os dados num relatório em papel, isso só seria possível com corte, colagem, muita paciência e vontade de gastar dinheiro. Também não era possível a criação de gráficos em papel, a não ser por meio de uso de marcadores, canetas e cartolina.

No principio dos anos 90, as empresas começaram a introduzir o conceito de base de dados nos seus produtos, mas continuou a faltar a facilidade de utilização. Até hoje persiste essa dificuldade, é difícil encontrar executivos que conheçam e saibam utilizar base de dados (FERAUCHE, 2006). A necessidade de dinamismo nas empresas levou ao desenvolvimento dos modernos sistemas de suporte à decisão. Um sistema de suporte à decisão é um sistema que proporciona aos seus utilizadores, não só um acesso rápido à sua informação particular, mas 
que também seja capaz de comparar esses dados com o restante da massa de informações do mercado e que tenha a capacidade de realizar análises e formatações na medida de suas necessidades (INMON, 1997). A utilização de ferramentas que permitam a captação, o gerenciamento e análise das informações, além do estabelecimento de estratégias internas e externas, são hoje fatores indispensáveis a qualquer empresa que deseje apresentar significativa participação no mercado.

Business Intelligence (BI), também conhecida como Knowledge Data Base Discovery (KDD), [...] "é uma terminologia usada para designar um processo de apoio inteligente na decisão utilizando fatos novos que podem ser úteis para uma organização aumentando, por exemplo, a participação no mercado e o número e variedade de clientes" (SHIMIZU, 2006, p. 335). Segundo o mesmo autor, o desenvolvimento deste novo tipo de instrumento de apoio à decisão se deve a pressão para aumentar a competitividade da empresa e o desejo de tirar proveito de investimentos efetuados na tecnologia da informação.

Inmon (1997) assinala que uma das ferramentas mais importantes que constituem a nova geração de Business Intelligence é o Data Warehouse que é definido como sendo uma coleção de dados orientados a assuntos, integrados, variáveis com o tempo e não voláteis. Os elementos de dados brutos que entram no Data Warehouse são oriundos, em quase todos os casos, do ambiente operacional não integrado (os antigos sistemas "legados"). O Data Warehouse é sempre um depósito de dados fisicamente separado do antigo ambiente operacional, onde todos os dados destes antigos sistemas são transformados antes de serem armazenados. O autor cita que o Data Warehouse é o ponto central da arquitetura de processamento de informações para sistemas de informática modernos suportando o processamento informacional - Sistema de Apoio à Decisão - (SAD) por meio de alicerce sólido de integração de dados corporativos e históricos para a realização de análises gerenciais. O Data Warehouse é construído e implementado de uma maneira evolucionária passo a passo, organizando e armazenando os dados necessários para a análise informacional e o processamento analítico sob uma perspectiva de longo prazo. A partir dos dados históricos básicos podem-se realizar análises de tendências. 
Dessa forma, o DW concentra as informações armazenadas, usualmente, estocadas em sistemas separados. Alguns desses dados podem estar em sistemas que usam tecnologias de gerenciamento de dados ultrapassadas, ou sistemas de arquivos nos quais as informações são de difícil acesso ao usuário. O DW "[...] é um banco de dados que armazena dados correntes e históricos de potencial interesse para os tomadores de decisão de toda a empresa. Os dados originam-se de muitos sistemas operacionais centrais, como sistemas de vendas, contas de clientes e manufatura, podendo incluir ainda dados advindos de transações em sites. O DW consolida e padroniza as informações oriundas de diferentes bancos de dados operacionais, de modo que elas possam ser usadas por toda a empresa para análise gerencial e tomada de decisões." (LAUDON, 2007, p. 149)

Sendo assim, os dados do DW ficam disponíveis para todos os empregados da organização que podem acessá-los de acordo com a sua necessidade, mas não podem ser alterados. O sistema de DW também oferece uma grande variedade de ferramentas customizadas e outras padronizadas, como ferramentas de consultas, analíticas e recursos de relatórios.

\subsection{O Gerenciamento dos Dados na Tomada de Decisão}

Conforme abordado anteriormente, são comumente encontradas nas empresas sistemas de informações gerenciais que geram grandes quantidades de dados em nível transacionais e operacionais. Para gerenciar essa grande massa de dados é necessário um sistema de gerenciamento de banco de dados (SGBD). "O SGBD é um tipo de software específico usado para criar, armazenar, organizar e acessar dados a partir de um banco de dados" (LAUDON, 2007, p.144). Para Haddad (2004, p.1) "banco de dados é um conjunto de informações interrelacionadas para uma determinada finalidade, por exemplo, cadastro de clientes, cadastro de produtos, controles de passagens aéreas, sistemas de vendas, etc.". 0 
banco de dados fornece acesso rápido e confiável à informação desejada e pode relacioná-las entre si e organizá-las a partir de um critério qualquer pré-selecionado que servirá de parâmetro para uma consulta.

Em um sistema de gerenciamento de banco de dados relacional (SGCBR) os dados podem ser manipulados em mais de um aplicativo ao mesmo tempo e podem-se estabelecer relações entre eles, buscando eliminar a duplicidade de informações, impondo integridade referencial, economizando espaço de cruzamento e facilitando a atualização (HADDAD, 2004). Isso significa que, uma vez elencado um elemento único e comum, presente em todas as tabelas do banco de dados, elas poderão ser relacionadas de forma a fazer os cruzamentos desejados das informações.

Alguns dos bancos de dados largamente utilizados pelas empresas hoje são o DB2 ${ }^{T M}$, o Oracle ${ }^{T M}$, e o Microsoft SQL Server ${ }^{T M}$ que são SGBDs para grandes mainframes e computadores de médio porte. Para as pequenas e médias empresas, bem como em usos pessoais, destacamos o Microsoft Access ${ }^{\mathrm{TM}}$ como solução de SGBD relacional de fácil utilização.

Sendo assim, com o SGDB o gestor encontra auxílio na tarefa de entender a separação da visão lógica e física dos dados na medida em que, na visão lógica apresenta os dados tais como seriam vistos por usuários da empresa, ao passo que na visão física, ele os encontra como estão realmente organizados e estruturados nos meios de armazenamento físico, como, por exemplo, em um Hard Disk (LAUDON, 2007). Na tarefa de manipular os dados, o gestor será capaz de gerar relatórios de maneira que os dados de seu interesse possam ser mostrados em um formato refinado e estruturado.

Um exemplo prático de utilização de pesquisa em banco de dados para um gestor de recursos humanos pode ser uma consulta onde se busca saber o nome do funcionário, a data de admissão na empresa e o setor a que ele pertence. Em um outro exemplo, o gestor responsável pela folha de pagamento poderia buscar as informações, nome do funcionário, setor a que ele pertence, seu salário e todos os recolhimentos e benefícios a ele vinculados. Em qualquer um dos casos, os dados advêm do mesmo banco de dados que é capaz de gerar múltiplas visões conforme a necessidade do gestor. 


\subsubsection{O Data Warehouse (DW)}

Reforçando a abordagem prévia, pode-se conceituar, o DW como sendo "[...] banco ou repositório de dados especial preparado para dar suporte a aplicações de tomada de decisões. As aplicações variam de simples gerações de relatórios ou consultas a complexas otimizações." (TURBAN et al., 2009, p.29). Por meio de utilização de DW os gestores e tomadores de decisão têm a capacidade de buscar informações sobre a empresa de forma a analisá-las e proporcionar suporte tático ou operacional às decisões e apresentarem uma imagem coerente das condições da empresa em determinado ponto no tempo.

\subsubsection{Processamento Analítico Online (OLAP)}

Existem muitas ferramentas de software que permitem aos gestores a geração de relatórios e consultas customizadas sob demanda. Originalmente, elas surgiram com o nome de processamento analítico online (OLAP). Por exemplo, na análise de um negócio é possível aos gestores rapidamente isolar e identificar produtos, clientes, regiões ou áreas que apresentem tendências de alta nas vendas em determinado período do ano (TURBAN et. al., 2009).

O OLAP permite a análise multidimensional de dados de forma que os usuários vejam os mesmos dados de diversas maneiras porque usa múltiplas dimensões. Cada aspecto da informação como, produto ou preço, representa uma dimensão diferente. Daí os gerentes setoriais podem utilizar uma ferramenta de análise multidimensional de dados para saber quantos produtos foram vendidos em determinada região e em determinada época do ano. O OLAP permite que os usuários obtenham respostas on-line a questões específicas, mesmo que os dados 
estejam armazenados em bancos de dados extremamente grandes (LAUDON, 2007).

\subsubsection{Data Mart (DM)}

Um DM é um subconjunto de um DW que normalmente consiste em uma única área temática, como, por exemplo, marketing ou operações (INMON, 1997). O DM é normalmente menor que o DW e concentra os assuntos afetos a apenas um departamento. O DM pode ser um subconjunto criado diretamente a partir de um DW e, nesse caso, classificado como DM dependente. Os independentes são pequenos e projetados para uma unidade estratégica de negócios ou um departamento.

\subsubsection{Data Mining}

Um passo muito importante na tomada de decisão gerencial é a habilidade de prever ou estimar resultados de procedimentos alternativos. Quando a previsão se torna muito complexa, a partir da análise de mais de duas variáveis, a utilização de uma ferramenta de previsão se torna imprescindível.

Um dos pontos fortes dos Data Minings, ou de mineração de dados, é a capacidade de extração automática, a partir de um banco de dados, de informações preditivas escondidas. Os Data Minings procuram por padrões em bancos de dados de operações amplas e baseiam a sua busca em fórmulas complexas de estatística (TURBAN et. al., 2009).

Os Data Minings são uma classe de análise de informações, baseada em bancos de dados, que procura padrões ocultos em uma tabela de dados que podem ser usados para prever comportamentos futuros. Turban et. al. (2009) alerta que o 
termo é comumente usado de forma equivocada para descrever um software que apresenta dados de novas maneiras, quando, de fato, o Data Mining descobre relações antes desconhecidas entre os dados e dessa forma utiliza esse conhecimento para alcançar metas específicas.

\subsubsection{Business Performance Management (BPM)}

Turban et. al. (2009) destacam que o componente final do processo de Bl é o BPM. Trata-se de uma estrutura que define, implementa e gerencia estratégias de negócios de uma empresa agrupando objetivos, ou seja, é uma forma de conectar métricas de nível superior, como informações financeiras, a desempenho reais em todos os níveis hierárquicos da organização. Dessa forma, o BPM usa a análise, a geração de relatórios e as consultas de BI com o objetivo de otimizar o desempenho geral da organização. Como conjunto integrado de processos, metodologias, métricas e aplicações projetadas com o intuito de melhorar o desempenho geral financeiro, tem por finalidade ajudar as empresas a converterem suas estratégias e objetivos em planos. Também foca o monitoramento do desempenho dos novos planos e analisa as variações entre os resultados reais e os planejados, bem como ajusta os objetivos e ações em reposta às análises.

O BPM engloba um conjunto de ciclo fechado de processos que vai desde a estratégia até a execução, de forma que otimiza o desempenho dos negócios. $O$ ciclo implica que o melhor desempenho é obtido pela definição das metas e objetivos, do estabelecimento de iniciativas e planos para alcançar essas metas, pelo monitoramento do desempenho real em relação às metas e objetivos, e pela tomada de ações corretivas (TURBAN et. al., 2009). 


\subsection{Os Benefícios do BI}

Os administradores necessitam de soluções de BI para melhor gerenciar os seus dados e as empresas que falham em implementar de forma adequada essas soluções se colocam em uma situação de desvantagem competitiva. No ambiente de negócios globalizado de hoje, a qualidade e a pontualidade da informação deixou de ser uma escolha entre lucro e perda e passou a ser entendida como uma questão de sobrevivência ou falência. Para garantir sucesso no ambiente de negócios as empresas devem avaliar a sua disponibilidade de enfrentamento em relação aos desafios impostos para as novas realidades do mercado, ter uma abordagem holística de funcionalidade de $\mathrm{BI}$, fazer uso das práticas recomendadas e antecipar custos antes ocultos. Com as ferramentas de BI é possível, por exemplo, gerar dados que colaborem com a inteligência competitiva $(\mathrm{Cl})$ da organização de forma a poder compará-los com a realidade onde a organização está inserida. Na verdade, Cl implica em acompanhar o que os concorrentes estão fazendo, e para poder fazer isso, as empresas devem ter a capacidade de gerar os seus próprios dados, aqueles certos que se encontram, às vezes, escondidos em transações incomuns.

O principal benefício do BI para a organização é a sua capacidade de fornecer informações precisas e imediatas quando solicitadas, dando uma visão em tempo real do desempenho corporativo global e de suas partes individualmente. Essas informações são de grande valia para todos na organização, especialmente aqueles que tomam decisões onde o planejamento estratégico está envolvido Turban et. al. (2009). Dentre os vários benefícios percebidos, destacamos:

- Economia de tempo;

- Versão única da informação;

- Melhores estratégias de planos;

- Melhores decisões táticas;

- Processos mais eficientes;

- Economia de custos; 
- Geração de relatórios mais precisos e de forma mais ágil;

- Melhor atendimento ao gestor;

- Melhora na receita, e;

- Melhor tomada de decisão.

Podem ser citados, ainda, os benefícios intangíveis obtidos por meio de $\mathrm{Bl}$, como valorização da marca, ao agregar agilidade de atendimento ao marketing da empresa.

Outro benefício apontado por Turban et. al. (2009) quando da utilização das ferramentas de $\mathrm{Bl}$ é a possibilidade de mensuração do retorno sobre o investimento (ROI) e do custo total de propriedade (TCO) para medir a relação custo / benefício dos projetos. Dessa forma, eles passam a ter a capacidade de medição de seus custos associados às fases do processo em geral, à manutenção da aplicação para os usuários do negócio e da velocidade do fluxo de caixa.

As tendências de $\mathrm{BI}$ apontam a ampliação constante e crescente no seu leque de usuários. Assim, tem permitido que os componentes desenvolvidos e instalados anteriormente em tecnologia da informação ( $\mathrm{TI}$ ) sejam aproveitados.

\section{MÉTODOS E TÉCNICAS DE PESQUISA}

\subsection{Tipo e Descrição Geral da Pesquisa}

Gil (2002) define pesquisa como o procedimento reacional e sistemático que tem como objetivo proporcionar respostas aos problemas que são propostos. $E$ destaca que ela é requerida quando não se dispõe de informação suficiente para 
responder ao problema, ou então quando a informação disponível se encontra em tal estado de desordem que na possa ser adequadamente relacionada ao problema.

Zanella (2006) aponta que a pesquisa tem por finalidade conhecer e explicar os fenômenos que ocorrem no mundo e definir, segundo duas finalidades amplas, qual seu enquadramento:

Vinculadas ao enriquecimento teórico da ciência; e

$\checkmark$ Relacionadas com valor prático ou pragmático.

Segundo a autora, essa primeira divisão especifica a pesquisa como científica pura ou pesquisa científica aplicada, ambas com as mesmas metas científicas e relacionadas com hipóteses, problema de pesquisa ou questão norteadora. A diferença básica entre elas está no método, no olhar do pesquisador e nos resultados da investigação.

$\checkmark$ Pesquisa científica pura - também denominada teórica ou básica, permite articular conceitos e sistematizar a produção de uma determinada área de conhecimento (MINAYO, 1996);

$\checkmark$ Pesquisa científica aplicada - Tem por finalidade gerar soluções aos problemas humanos e entender como lidar com um problema, conforme aponta Minayo (1996), ela pode contribuir com novos fatos para o planejamento de novas pesquisas ou mesmo para a compreensão teórica de certos setores do conhecimento.

Segundo o tipo de estudo, eles podem ser classificados em três tipos conforme sua finalidade:

$\checkmark$ Exploratórios - têm por finalidade ampliar o conhecimento a respeito de um determinado problema. Para Zanella (2006) explora a realidade buscando maior conhecimento, para depois planejar uma pesquisa descritiva;

$\checkmark$ Descritiva - procura conhecer a realidade estudada, suas características, seus problemas (ZANELLA, 2006).

$\checkmark$ Experimentais - Mais utilizados em ciências naturais e criticada pela suscetibilidade ao manuseio dos resultados pelo pesquisador. 
Sendo assim, neste trabalho foi utilizado o procedimento de pesquisa descritiva como forma de estudar e explicar as contribuições advindas da implantação de soluções de sistemas computadorizados e ferramentas de sistema de apoio à decisão para apoiar os gestores na tomada de decisão.

\subsection{Caracterização da Organização}

De acordo com os registros gentilmente cedidos pelo setor de memorial da instituição Beta é que as informações que se seguem puderam ser obtidas. A instituição atua, desde 1960, nos segmento esportivo e cultural. A história da Instituição está interligada com a construção de Brasília, e tem como patrono o idealizador da capital federal, Juscelino Kubitschek de Oliveira, que se referiu à instituição como sendo "a sala de visitas da nova metrópole". No decorrer dessas quase cinco décadas, muitas melhorias foram realizadas para aprimorar cada vez mais a estrutura e os serviços oferecidos ao quadro social.

O Plano Piloto da Nova Capital do Brasil - Brasília, ainda era um sonho, mas o arquiteto Lúcio Costa - responsável pela ponte urbanística da cidade, a mando do Presidente Juscelino Kubitschek - já tinha previsto a criação de uma sociedade recreativa, à beira do futuro Lago Paranoá. Com isto em mente, às 20 horas do dia 12 de setembro de 1959 (aniversário de JK) na Sede Social do clube Paranoá (antiga Novacap, hoje, Candangolândia), onze pioneiros da construção de Brasília se reuniram com o propósito de fundar esta instituição recreativa.

A associação foi organizada juridicamente como sociedade civil por cotas, sem fins lucrativos ou políticos, com o objetivo principal de estimular e desenvolver os esportes náuticos entre os associados. Uma comissão foi eleita responsável pelo seu desenvolvimento até que se atingisse um total de cinqüenta sócios proprietários quando, então, seria convocada uma Assembléia Geral, para a eleição de uma Diretoria e dos Conselhos Deliberativo e Fiscal.

A sede provisória ficou sendo o número 2125, da Avenida Central, do Núcleo Bandeirante, antiga Cidade Livre sendo que o Estatuto foi registrado no dia 17 de setembro de 1959, no Cartório da Comarca de Planaltina e a secretaria foi 
provisoriamente sediada em um apartamento da Super Quadra Sul 208. Só então o terreno para edificação do Clube foi doado para construção pela Novacap.

Em nível de direção, a estrutura hierárquica da instituição é composta pela Presidência, Conselho Deliberativo, Comissão Fiscal, Conselho Diretor e Conselho Deliberativo.

A Presidência é composta pelo Presidente, pelo $1^{\circ}$ Vice-Presidente e pelo $2^{\circ}$ Vice-Presidente e possui ainda três assessores.

O Conselho Deliberativo é composto pelo Presidente, $1^{\circ}$ Vice-Presidente, $2^{\circ}$ Vice-Presidente, $1^{\circ}$ Secretário e $2^{\circ}$ Secretário.

A Comissão Fiscal é composta pelo Presidente, dois integrantes efetivos e dois suplentes.

O Conselho Diretor é composto por 13 Diretores e 23 Vice-Diretores.

No nível mais alto do funcionalismo está situada a Superintendência que conta com um Superintendente e quatro Superintendentes Adjuntos. No segundo escalão estão os Chefes de Departamentos de tesouraria, secretaria, recursos humanos, patrimônio, engenharia e manutenção. Abaixo deles estão os Encarregados de Setores.

Atualmente a instituição conta com aproximadamente 500 funcionários e sua folha de pagamento, com encargos, gira em torno de 500 mil reais ao mês. A estrutura administrativa pode ser visualizada no organograma do Anexo A.

\subsection{Caracterização do Sistema}

O DW inicialmente foi desenvolvido com os arquivos em texto dos setores de contabilidade, financeiro e recursos humanos. A fim de integrar os dados extraídos dos diversos setores e armazená-los em repositório único, criou-se banco de dados em Access ${ }^{\mathrm{TM}}$. Para isso, foram criadas as tabelas tblDados, com todos os dados extraídos na etapa anterior, tabela tbIPlanoDeContas, com o plano de contas da instituição, tbIDepartamentos com a descrição dos departamentos da instituição, tblFuncionarios, com a relação de nomes, matrícula, setor, admissão e demissão de 
todos os funcionários da instituição, tblAuxMes, tabela auxiliar para classificação e padronização dos meses do ano. Em todas as tabelas foram definidas chaves primárias para assegurar a singularidade dos registros. Segundo a definição de HADDAD (2000), a chave primária é um campo único, ou conjunto de campos, que serve de referência para que o aplicativo possa diferenciar um registro de outro.

Para garantir a segurança do relacionamento e não permitir a eliminações ou acréscimos indevidos de registros nas tabelas, foi utilizado o atributo de integridade referencial. A integridade referencial propaga as atualizações dos campos relacionados, fazendo com que uma alteração no conteúdo da tabela primária seja refletida nas tabelas secundárias e, propaga exclusão de registros relacionados, fazendo com que exclusões no conteúdo da tabela primária também sejam refletidas nas secundárias (HADDAD, 2000). A Figura 3.3 a seguir mostra os relacionamentos e seus tipos, e as integridades referenciais impostas:

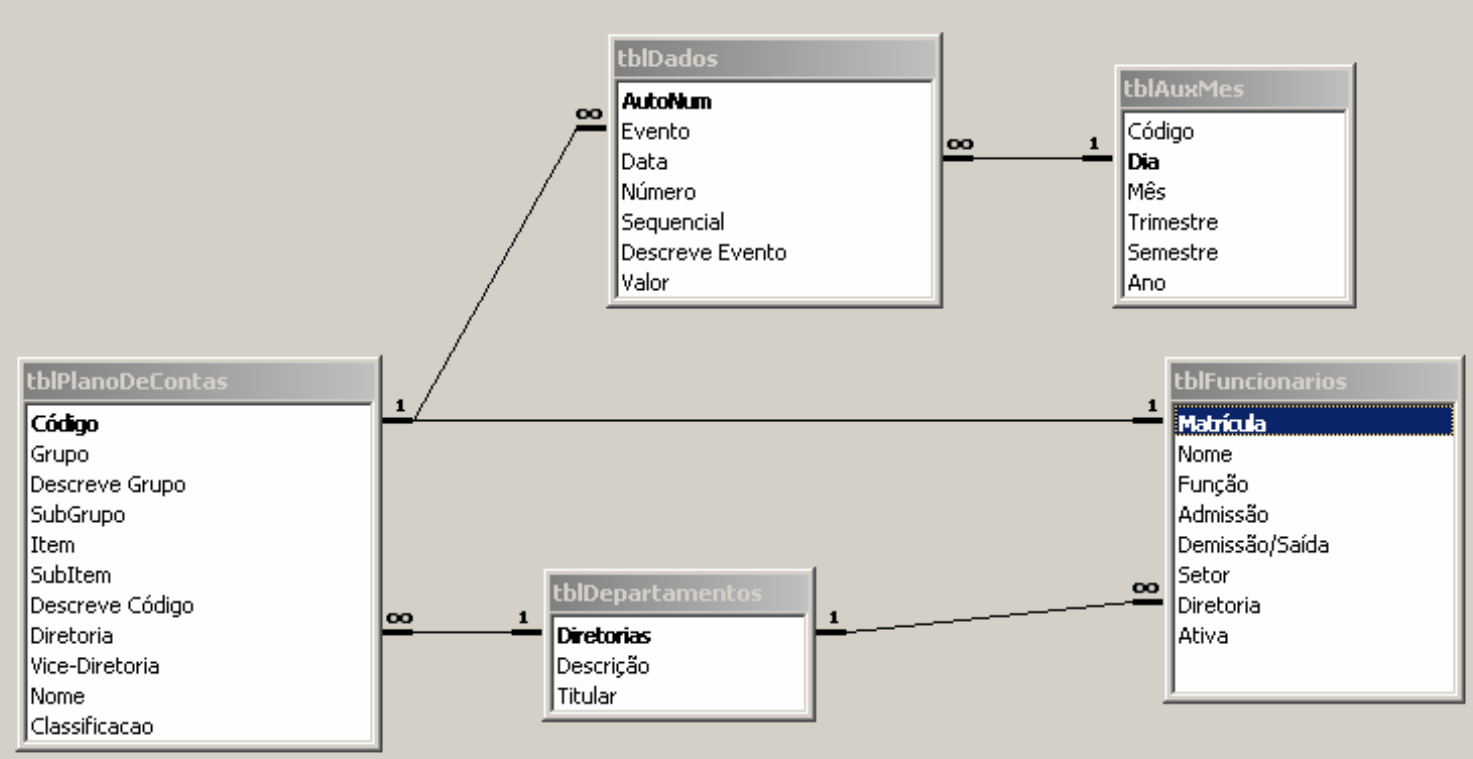


Após o povoamento das tabelas, foram definidas as consultas e construídos os relatórios setoriais. A partir daí, o banco de dados passou a conter as séries históricas, sendo utilizado como repositório único e centralizador para geração de dados para as tomadas de decisões.

\subsection{Os participantes do estudo}

Para a compreensão da organização em estudo foram utilizados múltiplos meios de pesquisa. Na primeira visita foram entrevistados os primeiros gestores da organização com o objetivo de entender de forma global a instituição e de identificar da maneira mais correta a população alvo que efetivamente utiliza os sistemas após a implantação das soluções tecnológicas de BI. Em seguida, apresentou-se a razão do trabalho ao presidente que forneceu uma visão geral da instituição. Foi realizado um estudo dos documentos da contabilidade e do departamento de Recursos Humanos a fim de verificar a necessidade de implantação de sistemas de informação.

Posteriormente, foram feitas perguntas abertas, por meio de entrevista baseada em questionário previamente elaborado, para formar um conhecimento inicial sobre os diversos aspectos inerentes à organização, relativos à sua finalidade, história, formalização, estruturas e funcionamento, bem como para entender sobre os pontos fortes e pontos fracos internos e externos à organização.

$\mathrm{Na}$ seqüência, foram realizadas novas visitas aos departamentos, bem como foram realizados diversos telefonemas, ao presidente, aos diretores e aos funcionários envolvidos com o objetivo de aprofundar conhecimentos, obter dados adicionais e desvendar conflitos de informações.

As ações mencionadas contribuíram muito para a formação do conhecimento da organização, mas sem dúvida alguma, o que mais propiciou a sua compreensão foram os estudos dos sistemas locais, modus operandi de cada 
departamento e estudo de documentos internos. Com estas ações tornou-se possível vivenciar a realidade da organização, seus anseios e dificuldades, possibilitando a obtenção de informações que extrapolavam a mera formalidade, alcançando aspectos comportamentais e culturais manifestados no universo submerso de suas relações informais.

A última etapa foi a aplicação do questionário (Apêndice $A$ ) às pessoas as quais se atribuem tomadas de decisão em vários níveis, desde a Presidência, passando pela Diretoria e os empregados com cargo de Chefia.

De acordo com informações disponibilizadas pela Instituição, foram identificados 85 usuários dos sistemas, que receberam o referido questionário dos quais 61 o responderam. Segundo a estratificação proposta por Lapponi (2000), dividimos o grupo em três categorias, presidência, diretoria e empregados.

Os questionários foram distribuídos pessoalmente a cada um dos usuários, com as informações pertinentes, para posterior devolução ao pesquisador, sendo que nesse momento foram esclarecidas as dúvidas por eles manifestadas. Após preenchimento e devolução dos questionários, os dados foram digitados e armazenados em tabelas do banco de dados do software Access ${ }^{\mathrm{TM}}$. A partir daí, os dados foram analisados e classificados de acordo com os níveis da escala Likert (WELLIANDRE et al., 2003) e exportados para o software Excel ${ }^{\mathrm{TM}}$, onde foram analisados.

\subsection{Caracterização do instrumento de pesquisa}

MATIAS-PEREIRA (2007) destaca os meios de investigação de uma pesquisa, dentre eles o documental como uma das formas de investigação. Inicialmente, neste trabalho, foram utilizados os documentos impressos do departamento de contabilidade da empresa, mais especificamente os balancetes e livros-razão. Do departamento de recursos humanos, extraíram-se planilhas eletrônicas de controle elaboradas em Excel $^{\mathrm{TM}}$ com o objetivo de verificar a situação 
anterior à implantação do sistema de apoio à decisão. No Departamento de Patrimônio observou-se o sistema local, montado em plataforma específica, com identificação de, por exemplo, registros de ingresso, nota fiscal, estoque, dentre outros.

Com relação ao processo de preparação e planejamento da pesquisa, Yin (2010) aborda os preparativos para a coleta de dados e recomenda formular boas questões, ser bom ouvinte, exercitar a adaptabilidade e a flexibilidade, ter noção clara dos assuntos em estudos e evitar o viés. Destaca também a importância do desenvolvimento lógico do questionário.

Para a presente pesquisa elaborou-se um questionário (Apêndice A) que teve como base a combinação proposta por Löbler et al. (2006) das categorias de análise do modelo de aceitação da tecnologia, ou Technology Acceptance Model (TAM), formulado por Davis (1989 apud LÖBLER et al. 2006) e pelo modelo de ajuste tecnologia-tarefa, ou Task Technology Fit (TTF) formulado pelos autores Goodhue e Thompson (1995 apud LÖBLER et al. 2006).

O modelo TAM, como outros estudos, é usado na intenção de explicar comportamentos de aceitação dos usuários frente à sistemas de informação. Segundo Davis (1996 apud LÖBLER et al., 2006) seu desenvolvimento deu-se pela adaptação do modelo de teoria da ação racionalizada, ou Theory of Reasoned Action (TRA) projetado para "[...] compreender a relação causal entre variáveis externas de aceitação dos usuários e o uso real do computador, buscando entender o comportamento deste usuário através do conhecimento da utilidade e da facilidade de utilização percebida."

No modelo TTF é mencionado que a adoção da tecnologia depende em parte da capacidade do atendimento às exigências a uma tarefa particular e sugere que a tecnologia só será utilizada se as opções fornecidas pelo sistema suportarem as atividade do usuário. Em relação ao modelo TAM, o TTF é mais amplo porque considera que a tarefa executada afeta o uso e também por considerar a variável inovadora "compatibilidade", que é descrita nesse modelo como o "grau pelo qual uma inovação é percebida como consistente, com a existência de valores, experiências passadas e as necessidades daqueles que adotarem tal inovação" (LÖBLER et al., 2006). 
Löbler (2006) cita que com a utilização do modelo TTF juntamente com o TAM, pode-se agregar dois aspectos diferentes, foco na tarefa e foco nas atitudes. Com esse enfoque, a combinação dos dois modelos gera uma melhor explicação sobre o uso da $\mathrm{TI}$ que somente as avaliações isoladas, das atitudes ou das tarefas não geraria.

O questionário desse estudo utilizou a combinação dos dois modelos proposto por Löbler (2006) utilizando os parâmetros ali descritos.

A elaboração das perguntas do questionário quantitativo da pesquisa baseou-se nas entrevistas, telefonemas, pesquisa do material disponibilizado pela organização e conversas informais com o corpo de funcionários, onde foram abordados, superficialmente, o propósito do estudo e expostas as noções básicas dos procedimentos a serem tomados.

\subsection{Procedimento de coleta e de análise de dados}

O trabalho foi realizado em quatro fases, a) entrevista diagnóstica com os gestores da instituição, b) análise de documentação, c) aplicação de questionário ao público alvo e d) análise dos resultados dos questionários.

Para a entrevista diagnóstica contou com a participação do Presidente da organização, dos diretores de secretaria, financeiro, informática, patrimônio e recursos humanos onde foi exposto o propósito do trabalho.

$\mathrm{Na}$ segunda fase foram analisados os documentos $e$ arquivos disponibilizados pela organização, já citados anteriormente, bem como vivenciou-se modus operandi de cada setor e observou-se como os documentos e arquivos eram utilizados.

Os questionários foram compostos por uma série de 25 perguntas classificadas segundo as categorias de análise de TTF e TAM. Os parâmetros definidos, de TTF foram:

Experiência com a ferramenta; 
$>$ Funcionalidade da ferramenta e,

$>$ Característica da tarefa

Os parâmetros de TAM abordados foram:

Atitude para o uso;

Intenção de usar a tecnologia;

Uso atual;

Facilidade de uso percebida e,

Utilidade percebida.

Não foi considerado o parâmetro atitude para o uso, pois utilizou-se a abordagem sugerida por Löbler (2006) que funde esse parâmetro com o de intenção de uso.

No segundo agrupamento as perguntas foram ordenadas e distribuídas em quatro dimensões pré-definidas e identificadas com problemas comuns em empresas que não possuem suporte computacional para apoio aos tomadores de decisão (TURBAN et al., 2009). As Classificações são conforme abaixo:

Intranet e Sistema;

Relatórios Financeiros;

Relatórios Gerenciais e,

$>$ Relatórios Específicos.

A categorização segundo os critérios e dimensões está na Tabela 3.1 Categoria e Dimensões abaixo: 


\begin{tabular}{|c|c|c|c|}
\hline Questao & Categoria de Sistema & Dimensão de TAM e TTF & TAM e TTF \\
\hline 1 Conheço e tenho acesso à Intranet do Clube & Intranet e Sistema & Experiência com a ferramenta & TTF \\
\hline 2 As informações da Intranet do Clube são úteis a mim & Intranet e Sistema & Utilidade percebida & TAM \\
\hline 3 Os dados disponibilizados, via WEB, pelo Clube, me são úteis & Intranet e Sistema & Utilidade percebida & TAM \\
\hline 4 O sistema do clube atende as minhas necessidades de informações gerenciais & Intranet e Sistema & Utilidade percebida & TAM \\
\hline 5 Retiro da Intranet as informações de que preciso para desempenhar a minha função & Intranet e Sistema & Funcionalidade da ferramenta & TTF \\
\hline 6 Acesso, periodicamente, os relatórios financeiros & Relatórios Financeiros & Experiência com a ferramenta & TTF \\
\hline 7 Recebo, periodicamente, relatórios gerenciais do meu Setor & Relatórios Gerenciais & Uso Atual & TAM \\
\hline 8 Recebo, periodicamente, relatórios com as despesas do Clube & Relatórios Financeiros & Uso Atual & TAM \\
\hline 9 Recebo, periodicamente, relatórios com as despesas do meu Setor & Relatórios Financeiros & Uso Atual & TAM \\
\hline 10 Recebo, periodicamente, relatórios com as receitas do Clube & Relatórios Financeiros & Uso Atual & TAM \\
\hline 11 Recebo, periodicamente, relatórios com as receitas do meu Setor & Relatórios Financeiros & Uso Atual & TAM \\
\hline 12 Recebo, periodicamente, relatórios da execução orçamentária do Clube & Relatórios Gerenciais & Uso Atual & TAM \\
\hline 13 Recebo, periodicamente, relatórios da execução orçamentária do meu Setor & Relatórios Gerenciais & Uso Atual & TAM \\
\hline 14 Consigo com facilidade informações gerencias do Clube & Relatórios Gerenciais & Facilidade de uso percebida & TAM \\
\hline 15 Consigo com facilidade informações gerencias do meu setor & Relatórios Gerenciais & Facilidade de uso percebida & TAM \\
\hline 16 Tenho facilidade de acesso a informações que necessito & Relatórios Gerenciais & Facilidade de uso percebida & TAM \\
\hline 17 É fácil alterar um relatório específico de despesas do meu setor & Relatórios Específicos & Características da tarefa & TTF \\
\hline 18 É fácil alterar um relatório específico de receitas do meu setor & Relatórios Específicos & Características da tarefa & TTF \\
\hline 19 Consigo com facilidade pesquisar informações específicas sobre as despesas do Clube & Relatórios Específicos & Funcionalidade da ferramenta & TTF \\
\hline 20 Consigo com facilidade pesquisar informações específicas sobre as despesas do meu setor & Relatórios Específicos & Funcionalidade da ferramenta & TTF \\
\hline 21 Tomo decisões baseadas nos números gerados pelo sistema & Relatórios Específicos & Intenção de usar a TI & TAM \\
\hline 22 Consigo facilmente os detalhes de despesas que necessito & Relatórios Específicos & Funcionalidade da ferramenta & TTF \\
\hline 23 Consigo facilmente os detalhes de receitas que necessito & Relatórios Específicos & Funcionalidade da ferramenta & TTF \\
\hline 24 Conheço as séries históricas de despesas do Clube & Relatórios Específicos & Uso Atual & TAM \\
\hline 25 Conheço as séries históricas de receitas do Clube & Relatórios Específicos & Uso Atual & TAM \\
\hline
\end{tabular}

Tabela 3.1 Categorias e Dimensões de TAM e TTF

Fonte: Elaborado pelo autor (2010)

As perguntas foram elaboradas por meio de afirmações escalonadas com a utilização da escala de Likert. As escalas de Likert dizem respeito a uma série de afirmações relacionadas ao objeto pesquisado, isto é, representam várias assertivas sobre um assunto. Os respondentes não apenas respondem se concordam ou não com as afirmações, mas também informam qual seu grau de concordância ou discordância. É atribuído um valor a cada resposta, que reflete a direção da atitude do respondente em relação a cada assertiva. O somatório das pontuações obtidas para cada afirmação é dado pela pontuação total da atitude de cada respondente. As escalas de Likert são confiáveis, simples de construir e permitem obter informações sobre o nível dos sentimentos dos respondentes, já que não precisam se restringir ao simples concordo/discordo (WELLIANDRE et al., 2003).

O procedimento usado na aplicação da escala de Likert neste estudo foi o seguinte: foram reunidas várias informações sobre os elementos considerados do 
sistema de apoio a decisão: Intranet e Sistemas, com 5 itens, sendo o valor máximo de cada item igual a 5 pontos e o total possível 25; Relatórios Específicos, com 9 itens, sendo o valor máximo de cada item igual a 5 pontos e o total possível 45; Relatórios Financeiros, com 5 itens, sendo o valor máximo de cada item igual a 5 pontos e o total possível 25. Relatórios Gerenciais, com 6 itens, sendo o valor máximo de cada item igual a 5 pontos e o total possível 30 . Estes itens foram apresentados aos respondentes que indicaram o grau de concordância ou discordância: Discordo Totalmente (1 ponto), Discordo Parcialmente (2 pontos), Indeciso (3 pontos), Concordo Parcialmente (4 pontos) e Concordo Totalmente (5 pontos).

Para cada sujeito foi feito um score final computando suas respostas de acordo com os valores atribuídos. A maior pontuação possível será a multiplicação do maior número utilizado (por exemplo, 5) pelo número de respostas, e a menor pontuação será a multiplicação do menor número utilizado (por exemplo, 1) pelo número de respostas desfavoráveis. Para análise global, a pontuação individual máxima totalizou 125 pontos e para facilitar a interpretação que indicou a atitude em relação ao problema apresentado, trabalhou-se em termos percentuais.

\section{RESULTADOS E DISCUSSÃO}

Entre os dias 31 de agosto e 17 de setembro de 2010, foram distribuídos 85 questionários aos diferentes usuários da instituição Beta, dos quais 3 da presidência, 18 da Diretoria e 64 empregados. Foram devolvidos 61 questionários, sendo 3 da presidência, 14 da Diretoria e 44 dos empregados, o que corresponde a, aproximadamente, $72 \%$ do total. A maior concentração de não respondentes agrupa-se entre os empregados (31\%) fato esse atribuído a férias, folgas, licenças, faltas, incompatibilidade de horários ocorridos nesse período, além de recusas ocasionais.

Para facilitar e melhor verificar o impacto do novo modelo de apoio à decisão, dividimos os resultados da pesquisa em 4 grupos, 1) Consolidado, 2) Presidência, 3) Diretoria e 4) Empregados. 


\subsection{Análise das Contribuições dos Usuários do Sistema sob a Ótica dos Modelos TTF e TAM}

São analisadas nesse tópico as contribuições dos participantes da pesquisa, à luz das reflexões abordadas nos modelos TTF e TAM, citados anteriormente. A estrutura da redação considera as reflexões das dimensões: 1) Característica da tarefa; 2) Experiência com a ferramenta; 3) Facilidade de uso percebida; 4) Funcionalidade da ferramenta; 5) Intenção de usar a tecnologia; 6) Uso atual e; 7) Utilidade percebida. O primeiro grupo apresenta os dados consolidados.

\begin{tabular}{|c|c|c|c|c|c|c|}
\hline Dimensão & 1) Nunca & 2) Raramente & 3) Às Vezes & 4) Geralmente & 5) Sempre & Total \\
\hline Características da tarefa & 38 & 27 & 35 & 15 & 7 & 122 \\
\hline Experiência com a ferramenta & 29 & 11 & 26 & 20 & 36 & 122 \\
\hline Facilidade de uso percebida & 26 & 46 & 36 & 42 & 33 & 183 \\
\hline Funcionalidade da ferramenta & 66 & 60 & 74 & 64 & 41 & 305 \\
\hline Intenção de usar a TI & 14 & 9 & 22 & 6 & 10 & 61 \\
\hline Uso Atual & 170 & 103 & 148 & 84 & 44 & 549 \\
\hline Utilidade percebida & 12 & 21 & 25 & 67 & 58 & 183 \\
\hline \multicolumn{7}{|l|}{ Grupo\% } \\
\hline Características da tarefa & $31 \%$ & $22 \%$ & $29 \%$ & $12 \%$ & $6 \%$ & \\
\hline Experiência com a ferramenta & $24 \%$ & $9 \%$ & $21 \%$ & $16 \%$ & $30 \%$ & \\
\hline Facilidade de uso percebida & $14 \%$ & $25 \%$ & $20 \%$ & $23 \%$ & $18 \%$ & \\
\hline Funcionalidade da ferramenta & $22 \%$ & $20 \%$ & $24 \%$ & $21 \%$ & $13 \%$ & \\
\hline Intenção de usar a TI & $23 \%$ & $15 \%$ & $36 \%$ & $10 \%$ & $16 \%$ & \\
\hline Uso Atual & $31 \%$ & $19 \%$ & $27 \%$ & $15 \%$ & $8 \%$ & \\
\hline Utilidade percebida & $7 \%$ & $11 \%$ & $14 \%$ & $37 \%$ & $32 \%$ & \\
\hline
\end{tabular}

Tabela 4.1. Visão das percentagens de aplicações e das notas atribuídas às respostas dos parâmetros TAM e TTF Instituição Beta - CONSOLIDADO -, Brasília - D.F., 2010

Fonte: Elaborado pelo autor (2010)

Em primeiro lugar investigou-se o resultado consolidado de todos os parâmetros agrupados. As contribuições contêm os pontos de vista dos 61 participantes da pesquisa. 
A primeira dimensão observada foi a da "característica da tarefa" que aborda a habilidade de ajuste de tecnologia-tarefa do modelo TTF. Nessa dimensão estão inseridas as habilidades de customização de saídas.

Observa-se que os usuários do sistema estão situados, em sua maioria (82\%) nos níveis entre 1 e 3 da escala, sugerindo dificuldade em executar alterações de, por exemplo, relatórios de maneira geral. A falta de treinamento pode ser uma explicação a situação apresentada, já que o sistema tinha menos de um ano de implantação definitiva, ou mesmo pela facilidade de execução do modelo anterior ( Figura 4.1.1.).

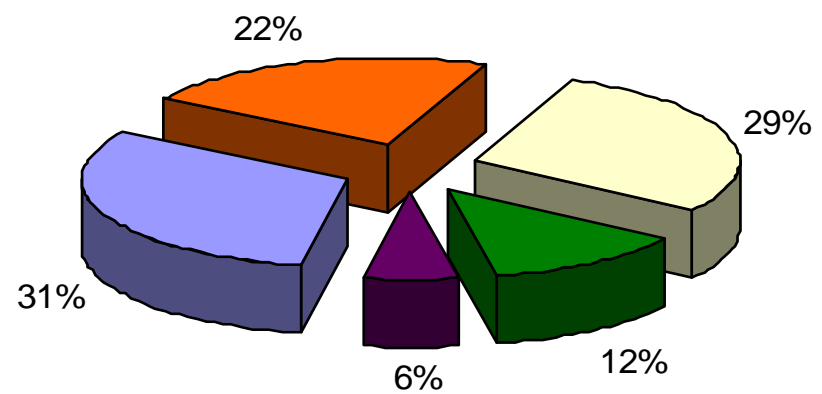

口1) Nunca $\square$ 2) Raramente $\square$ 3) Às Vezes $\square$ 4) Geralmente $\square$ 5) Sempre

Figura 4.1.1. Percentagens de Característica da tarefa - Consolidado Fonte: Elaborado pelo autor (2010)

Na observação da dimensão "experiência com a ferramenta", parâmetro de TTF, são avaliados os parâmetros como, por exemplo, acesso e entendimento do novo sistema. Os resultados corroboram o entendimento de pouca vivência com 0 novo sistema visto que $54 \%$ dos usuários situam-se entre os níveis 1 e 3 (Figura 4.1.2). 


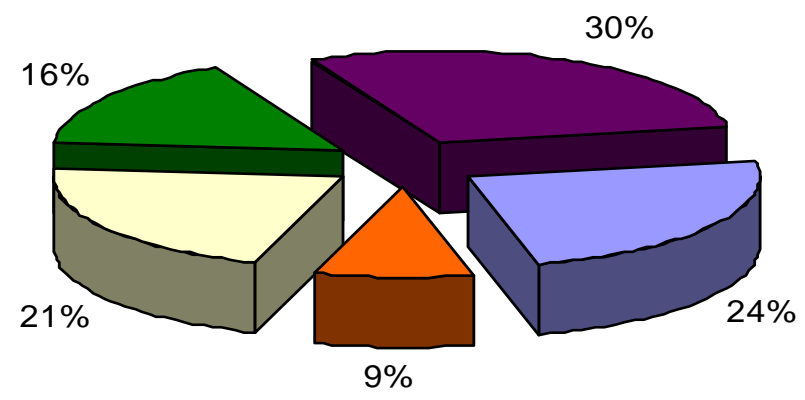

$\square$ 1) Nunca $\square$ 2) Raramente $\square$ 3) Às Vezes $\square$ 4) Geralmente $\square$ 5) Sempre

Figura 4.1.2. PerCenTAgens de EXPERIÊNCIA COM A FERRAMENTA - CONSOLIDAdO Fonte: Elaborado pelo autor (2010)

$\mathrm{Na}$ dimensão "facilidade de uso percebida", parâmetro de aceitação da tecnologia, foram estudados itens como, por exemplo, facilidades de navegação para acesso à informação. Percebe-se que os usuários apresentaram tendência central de comportamento, estando $68 \%$ deles situados entre os níveis 2 e 4 , tendo ainda $14 \%$ no nível 1 e $18 \%$ no nível 5 . No entanto, em outra visão verifica-se que $61 \%$ encontram-se entre os níveis 3 e 5 . Sendo assim, classificou-se o parâmetro como satisfatório (Figura 4.1.3.).

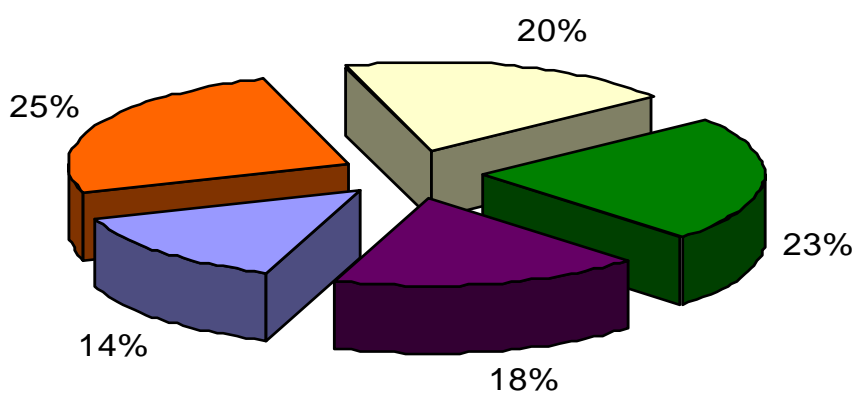

$\square$ 1) Nunca $\square$ 2) Raramente $\square$ 3) Às Vezes $\square$ 4) Geralmente $\square$ 5) Sempre 
$\mathrm{Na}$ dimensão "funcionalidade da ferramenta", parâmetro de ajuste de tecnologia tarefa, são abarcados itens como, por exemplo, alcance a detalhes e pesquisas setoriais específicas. Verifica-se que os usuários do sistema apresentaram tendência central de comportamento, estando $24 \%$ deles situados no nível 3, sendo essa a maior representatividade separadamente. Entre os satisfeitos, situados entre os níveis 4 e 5 , encontram-se $34 \%$ dos usuários, e entre os insatisfeitos, ou seja, entre os níveis 1 e 2, estão $41 \%$ do total, arredondando-se 0 resultado, o que denota certa insatisfação nesse critério (Figura 4.1.4.).

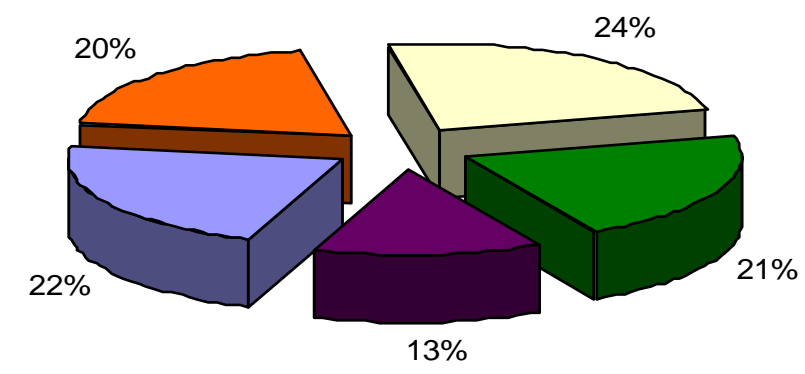

$\square$ 1) Nunca $\square$ 2) Raramente $\square$ 3) Às Vezes $\square$ 4) Geralmente $\square$ 5) Sempre

Figura 4.1.4. Percentagens de Funcionalidade da Ferramenta - CONSOlidado Fonte: Elaborado pelo autor (2010)

$\mathrm{Na}$ dimensão "intenção de uso da tecnologia", parâmetro do modelo de aceitação de tecnologia, são englobados os itens de confiabilidade do sistema, item de forte valor na tomada de decisão. Observa-se que os usuários do sistema apresentaram tendência central de comportamento, estando $36 \%$ deles situados no nível 3, sendo essa a maior representatividade separadamente. Entre os satisfeitos, situados entre os níveis 4 e 5 , encontram-se $26 \%$ dos usuários, e entre os insatisfeitos, ou seja, entre os níveis 1 e 2, estão 38\% do total, arredondando-se o resultado. Dessa forma sugere-se que o novo sistema ainda não apresenta a confiabilidade esperada (Figura 4.1.5). 


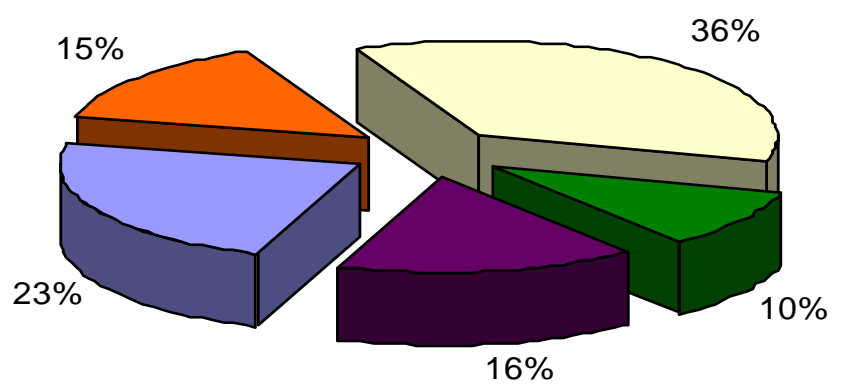

$\square$ 1) Nunca $\square$ 2) Raramente $\square$ 3) Às Vezes $\square$ 4) Geralmente $\square$ 5) Sempre

Figura 4.1.5. Percentagens de INTENÇão de USAR a TI - CONSOLIDAdo Fonte: Elaborado pelo autor (2010)

Na dimensão "uso atual", parâmetro do modelo de aceitação de tecnologia, são identificados itens de uso rotineiro, como, por exemplo, acesso a relatórios. Cerca de $77 \%$ dos usuários, considerando os níveis de 1 a 3, estão insatisfeito com as funções, corroborando o que aponta o parâmetro de funcionalidade da ferramenta. Entre os satisfeitos, situados entre os níveis 4 e 5, encontram-se apenas $23 \%$ dos usuários, e entre os insatisfeitos, ou seja, entre os níveis 1 e 2, estão $50 \%$ do total, arredondando-se o resultado. Este resultado sugere que o novo sistema ainda não é explorado de maneira adequada (Figura 4.1.6).

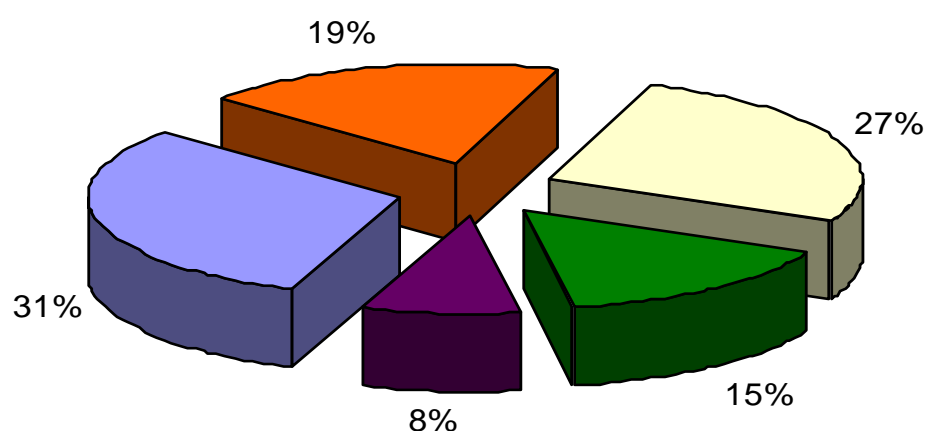

$\square$ 1) Nunca $\square$ 2) Raramente $\square$ 3) Às Vezes $\square$ 4) Geralmente $\square$ 5) Sempre

Figura 4.1.6. Percentagens de Uso atual - Consolidado Fonte: Elaborado pelo autor (2010) 
$\mathrm{Na}$ observação da dimensão "utilidade percebida", parâmetro de TTF, avaliaram-se parâmetros como, por exemplo, atendimento de expectativas e usabilidade das informações. Esse parâmetro reforça inteiramente a percepção da potencialidade da ferramenta, pois $68 \%$ dos usuários consideraram-se satisfeitos, situando-se entre os níveis 4 e 5 da escala. Depreende-se que, apesar da satisfação apontada aqui, ainda existe enorme potencial a ser alcançado pela ferramenta quando confrontados esses resultados com os anteriores (Figura 4.1.7).

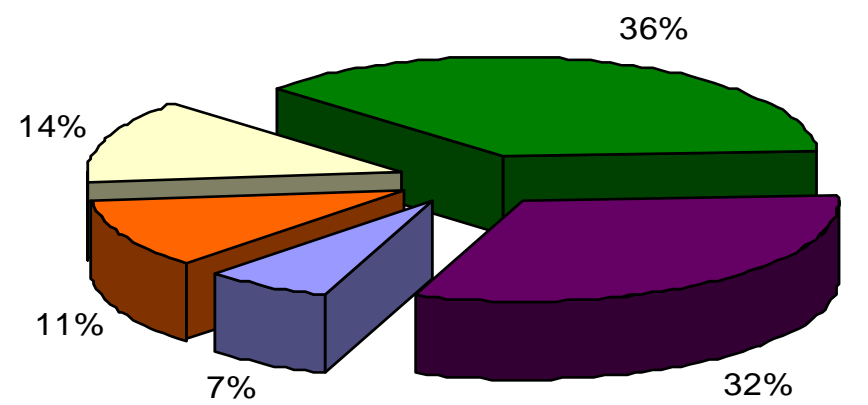

$\square$ 1) Nunca $\square$ 2) Raramente $\square$ 3) Às Vezes $\square$ 4) Geralmente $\square$ 5) Sempre

Figura 4.1.7. Percentagens de UTILIDADE PERCEBIDA - CONSOLIDAdo Fonte: Elaborado pelo autor (2010)

\subsubsection{Presidência}

Abordam-se aqui os resultados relativos aos usuários da presidência, gestores maiores da organização. As contribuições contêm os pontos de vista dos 3 participantes da pesquisa que representam apenas $5 \%$ do total de participantes. 


\begin{tabular}{|c|c|c|c|c|c|c|}
\hline Dimensão & 1) Nunca & \multicolumn{2}{|c|}{ 2) Raramente 3) Às Vezes } & \multicolumn{2}{|c|}{ 4) Geralmente 5) Sempre } & Total \\
\hline Características da tarefa & 2 & 3 & 1 & 0 & 0 & 6 \\
\hline Experiência com a ferramenta & 1 & 0 & 0 & 3 & 2 & 6 \\
\hline Facilidade de uso percebida & 2 & 6 & 1 & 0 & 0 & 9 \\
\hline Funcionalidade da ferramenta & 3 & 9 & 1 & 1 & 1 & 15 \\
\hline Intenção de usar a TI & 1 & 2 & 0 & 0 & 0 & 3 \\
\hline Uso Atual & 22 & 2 & 1 & 0 & 2 & 27 \\
\hline Utilidade percebida & 1 & 3 & 1 & 4 & 0 & 9 \\
\hline \multicolumn{7}{|l|}{ Grupo\% } \\
\hline Características da tarefa & $33 \%$ & $50 \%$ & $17 \%$ & $0 \%$ & $0 \%$ & \\
\hline Experiência com a ferramenta & $17 \%$ & $0 \%$ & $0 \%$ & $50 \%$ & $33 \%$ & \\
\hline Facilidade de uso percebida & $22 \%$ & $67 \%$ & $11 \%$ & $0 \%$ & $0 \%$ & \\
\hline Funcionalidade da ferramenta & $20 \%$ & $60 \%$ & $7 \%$ & $7 \%$ & $7 \%$ & \\
\hline Intenção de usar a TI & $33 \%$ & $67 \%$ & $0 \%$ & $0 \%$ & $0 \%$ & \\
\hline Uso Atual & $81 \%$ & $7 \%$ & $4 \%$ & $0 \%$ & $7 \%$ & \\
\hline Utilidade percebida & $11 \%$ & $33 \%$ & $11 \%$ & $44 \%$ & $0 \%$ & \\
\hline
\end{tabular}

Tabela 4.2. Visão das percentagens de aplicações e das notas atribuídas às respostas dos parâmetros TAM e TTF Instituição Beta - PRESIDÊNCIA -, Brasília - D.F., 2010

Fonte: Elaborado pelo autor (2010)

A primeira dimensão observada foi a da "característica da tarefa" que aborda a habilidade de ajuste de tecnologia-tarefa do modelo TTF. Nessa dimensão estão inseridas as habilidades de customização de saídas. Observa-se que os usuários do sistema situam-se, em sua totalidade entre os níveis entre 1 e 3 da escala, sugerindo dificuldade em executar alterações de, por exemplo, relatórios de maneira geral. A falta de treinamento pode ser uma explicação a situação apresentada, já que o sistema tinha menos de um ano de implantação definitiva, ou mesmo pela facilidade de execução do modelo anterior (Figura 4.2.1).

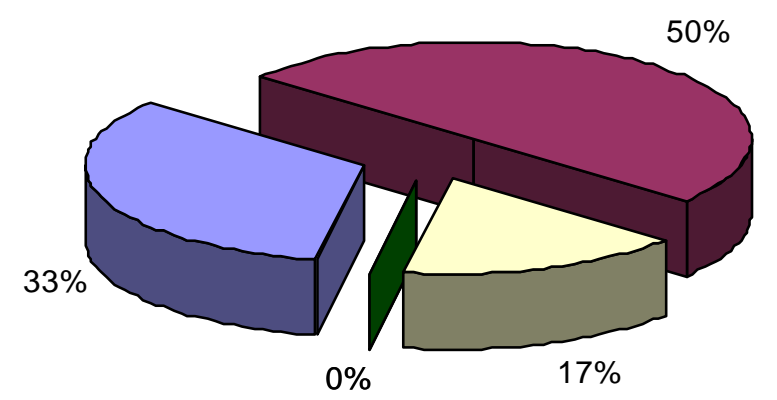
口1) Nunca
口) Raramente
口3) Às Vezes
4) Geralmente
5) Sempre

Figura 4.2.1. Percentagens de Característica da tarefa - Presidência Fonte: Elaborado pelo autor (2010) 
Na observação da dimensão "experiência com a ferramenta", parâmetro de TTF, são avaliados os parâmetros como, por exemplo, acesso e entendimento do novo sistema. Os resultados mostram satisfação para $83 \%$ dos usuários, localizados entre os níveis 4 e 5 da escala (Figura 4.2.2).

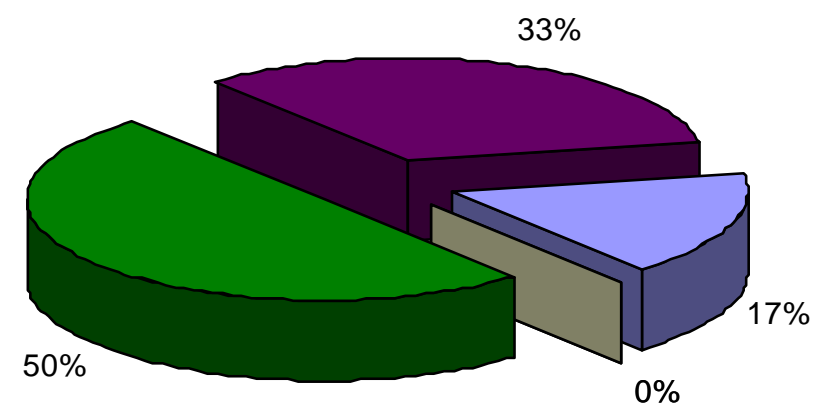
口1) Nunca
2) Raramente
口3) Às Vezes
4) Geralmente
5) Sempre

Figura 4.2.2. Percentagens de EXPeriênCIA Com a Ferramenta - PresidênCia Fonte: Elaborado pelo autor (2010)

$\mathrm{Na}$ dimensão "facilidade de uso percebida", parâmetro de aceitação da tecnologia, abordam-se itens como, por exemplo, facilidades de navegação para acesso à informação. Identifica-se que os usuários apresentaram insatisfação com o sistema estando $67 \%$ localizados no nível 2 da escala e $22 \%$ no nível 1 . Sendo assim, classificou-se como insatisfatório o parâmetro (Figura 4.2.3). 


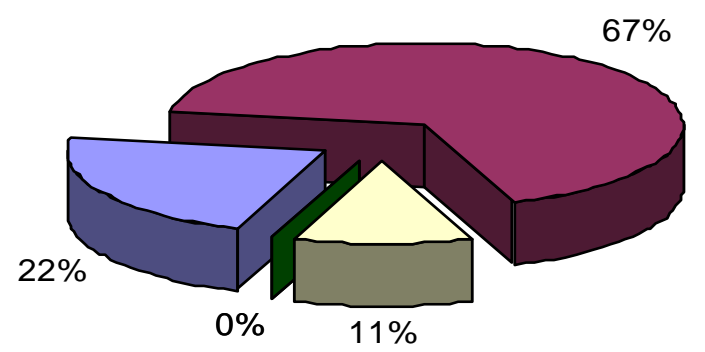
๑1) Nunca
2) Raramente
口3) Às Vezes
4) Geralmente
5) Sempre

Figura 4.2.3. Percentagens de FaCILIDAde de uso PERCEBIDA - PrEsidÊNCIA Fonte: Elaborado pelo autor (2010)

$\mathrm{Na}$ dimensão "funcionalidade da ferramenta", parâmetro de ajuste de tecnologia tarefa, são abarcados itens como, por exemplo, alcance a detalhes e pesquisas setoriais específicas. Verifica-se que os usuários do sistema apresentaram descontentamento, estando $60 \%$ deles situados no nível 2, sendo essa a maior representatividade separadamente. Entre os satisfeitos, situados entre os níveis 4 e 5 , encontram-se apenas 14\% dos usuários (Figura 4.2.4).

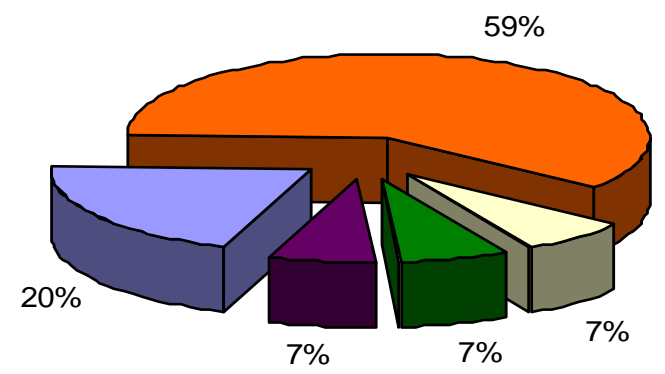
1) Nunca
2) Raramente
口3) Às Vezes
4) Geralmente
5) Sempre

Figura 4.2.4. Percentagens de Funcionalidade da ferramenta - PresidênCia Fonte: Elaborado pelo autor (2010) 
$\mathrm{Na}$ dimensão "intenção de uso da tecnologia", parâmetro do modelo de aceitação de tecnologia, são englobados os itens de confiabilidade do sistema, item de forte valor na tomada de decisão. Observa-se que os usuários do sistema apresentaram insatisfação, estando $67 \%$ deles situados no nível 2, sendo essa a maior representatividade quando considerados nos outros quatro parâmetros. Esse resultado sugere que o novo sistema ainda não apresenta a confiabilidade esperada (Figura 4.2.5).



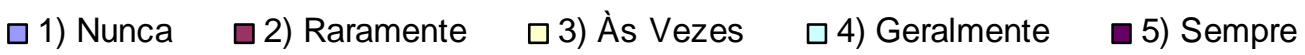

Figura 4.2.5. Percentagens de InTenÇão de USAR a TI - PreSidÊnCIa Fonte: Elaborado pelo autor (2010)

Na dimensão "uso atual", parâmetro do modelo de aceitação de tecnologia, são identificados itens de uso rotineiro, como, por exemplo, acesso a relatórios. Verifica-se que $81 \%$ dos usuários estão localizados no nível 1 da escala demonstrando a não utilização do sistema, o que pode ser a causa dos níveis de insatisfação dos outros resultados desse setor. Tal dado sugere que o novo sistema ainda não é explorado de maneira adequada (Figura 4.2.6). 


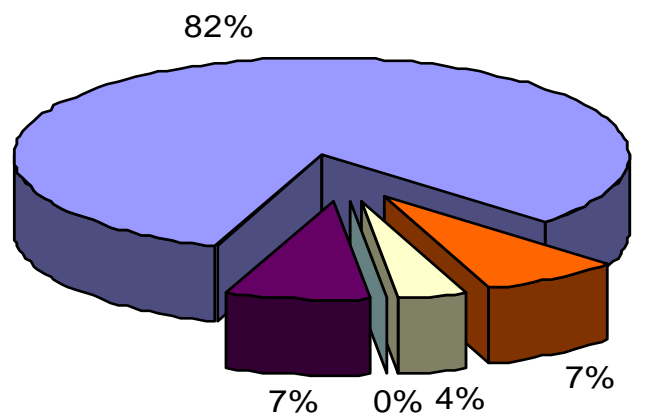

$\square$ 1) Nunca $\square$ 2) Raramente $\square 3$ ) Às Vezes $\square$ 4) Geralmente $\square$ 5) Sempre

Figura 4.2.6. Percentagens de Uso atual - PresidênCIA Fonte: Elaborado pelo autor (2010)

Na observação da dimensão "utilidade percebida", parâmetro de TTF, são avaliados parâmetros como, por exemplo, atendimento de expectativas e usabilidade das informações. Esse parâmetro reforça inteiramente a percepção da potencialidade da ferramenta, pois $44 \%$ dos usuários consideraram-se satisfeitos, situando-se no nível 4 da escala. Depreende-se que, apesar da satisfação apontada aqui, ainda existe enorme potencial a ser alcançado pela ferramenta quando confrontados esses resultados com os anteriores (Figura 4.2.7).

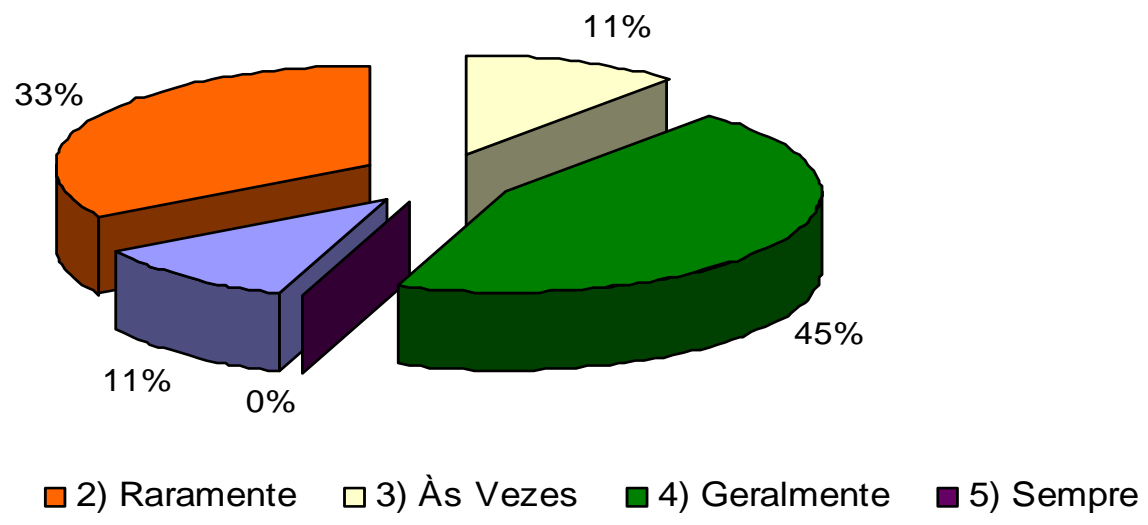

Figura 4.2.7. Percentagens de Utilidade Percebida - PresidênCia Fonte: Elaborado pelo autor (2010) 


\subsubsection{Diretoria}

Analisa-se aqui o grupo dos diretores. As contribuições contêm os pontos de vista dos 14 participantes da pesquisa que representam $23 \%$ do total de participantes.

\begin{tabular}{|c|c|c|c|c|c|c|}
\hline Dimensão & 1) Nunca & 2) Raramente & zes & 4) Geralmente & Sempre & Total \\
\hline Características da tarefa & 11 & 8 & 3 & 6 & 0 & 28 \\
\hline Experiência com a ferramenta & 3 & 3 & 5 & 6 & 11 & 28 \\
\hline Facilidade de uso percebida & 8 & 17 & 6 & 10 & 1 & 42 \\
\hline Funcionalidade da ferramenta & 13 & 24 & 5 & 21 & 7 & 70 \\
\hline Intenção de usar a TI & 2 & 4 & 6 & 1 & 1 & 14 \\
\hline Uso Atual & 44 & 35 & 19 & 24 & 4 & 126 \\
\hline Utilidade percebida & 0 & 6 & 5 & 15 & 16 & 42 \\
\hline \multicolumn{7}{|l|}{ Grupo\% } \\
\hline Características da tarefa & $39 \%$ & $29 \%$ & $11 \%$ & $21 \%$ & $0 \%$ & \\
\hline Experiência com a ferramenta & $11 \%$ & $11 \%$ & $18 \%$ & $21 \%$ & $39 \%$ & \\
\hline Facilidade de uso percebida & $19 \%$ & $40 \%$ & $14 \%$ & $24 \%$ & $2 \%$ & \\
\hline Funcionalidade da ferramenta & $19 \%$ & $34 \%$ & $7 \%$ & $30 \%$ & $10 \%$ & \\
\hline Intenção de usar a TI & $14 \%$ & $29 \%$ & $43 \%$ & $7 \%$ & $7 \%$ & \\
\hline Uso Atual & $35 \%$ & $28 \%$ & $15 \%$ & $19 \%$ & $3 \%$ & \\
\hline Utilidade percebida & $0 \%$ & $14 \%$ & $12 \%$ & $36 \%$ & $38 \%$ & \\
\hline
\end{tabular}

Tabela 4.3. Visão das percentagens de aplicações e das notas atribuídas às respostas dos parâmetros TAM e TTF Instituição Beta - DIRETORIA -, Brasília - D.F., 2010

Fonte: Elaborado pelo autor (2010)

A primeira dimensão observada foi a da "característica da tarefa" que aborda a habilidade de ajuste de tecnologia-tarefa do modelo TTF. Nessa dimensão estão inseridas as habilidades de customização de saídas. Observa-se que os diretores situam-se, em sua maioria (79\%) nos níveis entre 1 e 3 da escala, sugerindo dificuldade em executar alterações de, por exemplo, relatórios de maneira geral. A falta de treinamento pode ser uma explicação a situação apresentada, já que o sistema tinha menos de um ano de implantação definitiva, ou mesmo pela 
facilidade de execução do modelo anterior (Figura 4.3.1).

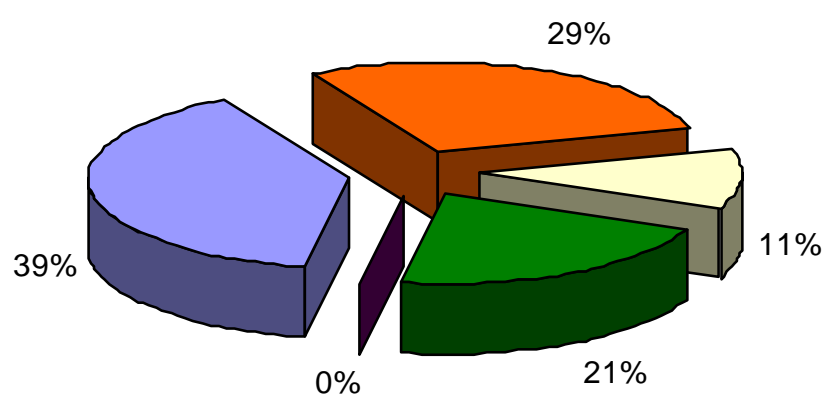

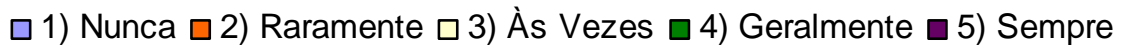

Figura 4.3.1. PERCENTAgENS de CARACTERÍstica da tarefa - Diretoria Fonte: Elaborado pelo autor (2010)

Na observação da dimensão "experiência com a ferramenta", parâmetro de TTF, são avaliados os parâmetros como, por exemplo, acesso e entendimento do novo sistema. Os resultados demonstram que os diretores estão satisfeitos com o novo sistema, visto que a maior percentagem situa-se no nível 5 com 39\% e $21 \%$ no nível 4, apesar da insatisfação demonstrada com a dimensão anterior (Figura 4.3.2).

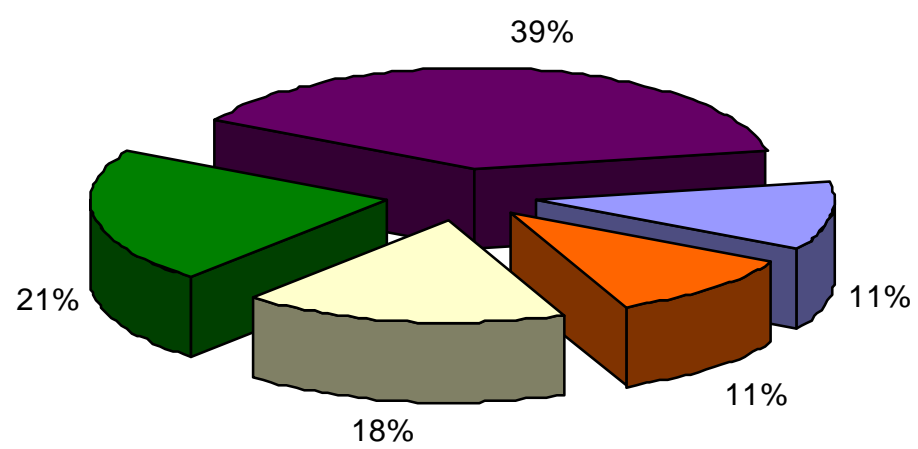

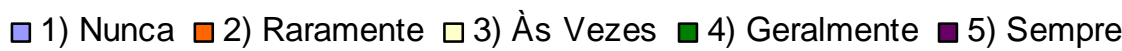

Figura 4.3.2. PERCENTAGENS de EXPERIÊNCIA COM A FERRAMENTA - DiretORIA Fonte: Elaborado pelo autor (2010) 
$\mathrm{Na}$ dimensão "facilidade de uso percebida", parâmetro de aceitação da tecnologia, foram abordados itens como, por exemplo, facilidades de navegação para acesso à informação. Identifica-se que os diretores demonstraram insatisfação, já que $60 \%$ deles escolheram os níveis 1 e 2, tendo ainda 14\% no nível 3 (Figura 4.3.3).

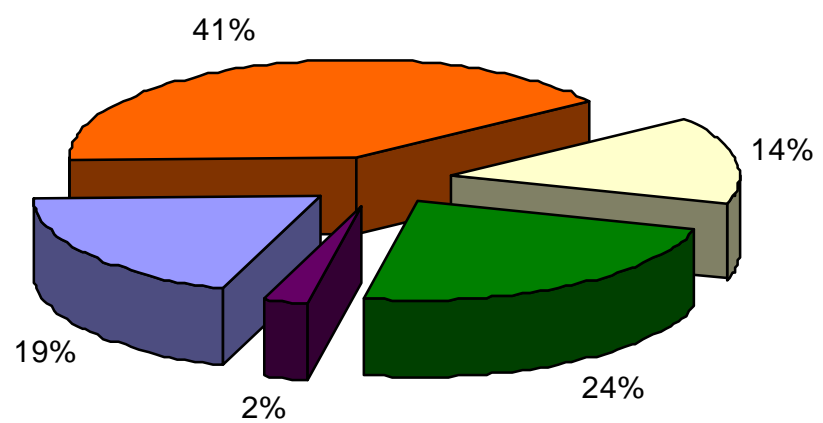

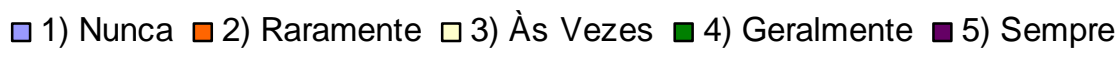

Figura 4.3.3. PERCENTAgens de FACILIDAdE de USO PERCEBIDA - Diretoria Fonte: Elaborado pelo autor (2010)

$\mathrm{Na}$ dimensão "funcionalidade da ferramenta", parâmetro de ajuste de tecnologia tarefa, são abarcados itens como, por exemplo, alcance a detalhes e pesquisas setoriais específicas. Observa-se que os diretores dividem-se entre satisfeitos (40\%), tendo escolhido os níveis 4 e 5 , e insatisfeitos (53\%), tendo escolhido os níveis 1 e 2 . O resultado sugere que há equilíbrio nesse critério (Figura 4.3.4). 


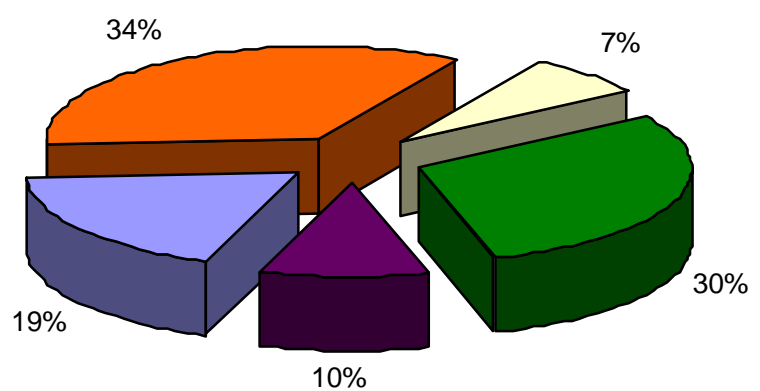

$\square$ 1) Nunca $\square$ 2) Raramente $\square$ 3) Às Vezes $\square$ 4) Geralmente $\square$ 5) Sempre

Figura 4.3.4. Percentagens de Funcionalidade da FerRamenta - Diretoria Fonte: Elaborado pelo autor (2010)

$\mathrm{Na}$ dimensão "intenção de uso da tecnologia", parâmetro do modelo de aceitação de tecnologia, são englobados os itens de confiabilidade do sistema, item de forte valor na tomada de decisão. Verifica-se que os diretores apresentaram tendência central de comportamento, estando $43 \%$ deles situados no nível 3, sendo essa a maior representatividade quando considerados nos outros quatro parâmetros. Entre os satisfeitos, situados entre os níveis 4 e 5, encontram-se $14 \%$ dos diretores, e entre os insatisfeitos, ou seja, entre os níveis 1 e 2, estão $43 \%$ do total, arredondando-se o resultado. Esse resultado denota que o novo sistema ainda não apresenta a confiabilidade esperada (Figura 4.3.5).



$\square$ 1) Nunca $\square$ 2) Raramente $\square$ 3) Às Vezes $\square$ 4) Geralmente $\square$ 5) Sempre 
Na dimensão "uso atual", parâmetro do modelo de aceitação de tecnologia, foram avaliados itens de uso rotineiro, como, por exemplo, acesso a relatórios. Verifica-se que $78 \%$ dos diretores encontram-se nos níveis de 1 a 3, demonstrando insatisfação com as funções, corroborando o que aponta o parâmetro de funcionalidade da ferramenta. Entre os satisfeitos, situados entre os níveis 4 e 5 , encontram-se apenas $22 \%$ dos diretores, e entre os insatisfeitos, ou seja, entre os níveis 1 e 2, estão 63\% do total, aproximadamente. Observa-se que o novo sistema ainda não é explorado de maneira adequada (Figura 4.3.6).

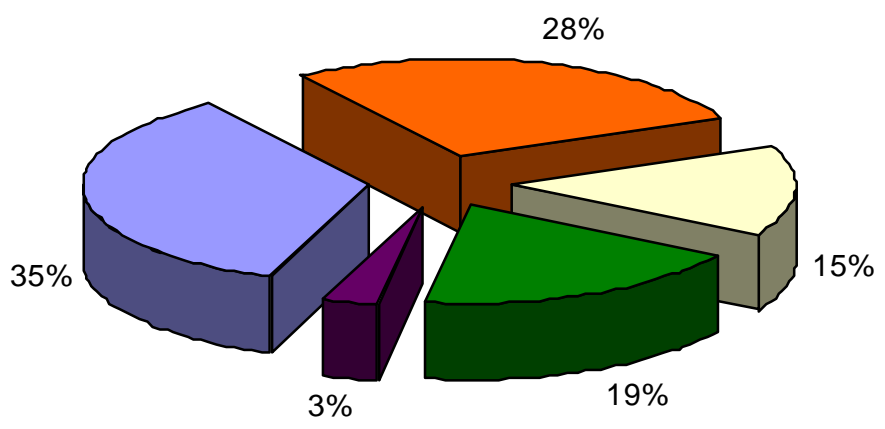

$\square$ 1) Nunca $\square$ 2) Raramente $\square$ 3) Às Vezes $\square$ 4) Geralmente $\square$ 5) Sempre

Figura 4.3.6. Percentagens de Uso atual - Diretoria -

Fonte: Elaborado pelo autor (2010)

Na observação da dimensão "utilidade percebida", parâmetro de TTF, foram avaliados parâmetros como, por exemplo, atendimento de expectativas e usabilidade das informações. Esse parâmetro reforçou inteiramente a percepção da potencialidade da ferramenta, pois $74 \%$ dos diretores consideraram-se satisfeitos, situando-se entre os níveis 4 e 5 da escala. Depreende-se que, apesar da satisfação apontada em outras dimensões, ainda existe enorme potencial a ser alcançado pela ferramenta (Figura 4.3.7). 


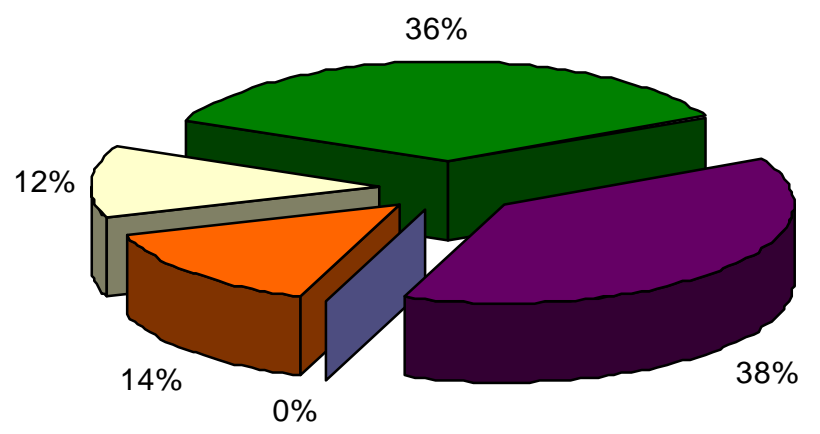

$\square$ 1) Nunca $\square$ 2) Raramente $\square$ 3) Às Vezes $\square$ 4) Geralmente $\square$ 5) Sempre

Figura 4.3.7. Percentagens de Utilidade PerCEBIDA - Diretoria -

Fonte: Elaborado pelo autor (2010)

\subsubsection{Empregados}

São analisados, a seguir, o maior grupo, o dos empregados. As contribuições contêm os pontos de vista dos 44 participantes da pesquisa que representam $72 \%$ do total de participantes.

\begin{tabular}{|c|c|c|c|c|c|c|}
\hline Dimensão & 1) Nunca & 2) Raramente 3 & 3) Às Vezes & 4) Geralmente 5) & Sempre & Total \\
\hline Características da tarefa & 25 & 16 & 31 & 9 & 7 & 88 \\
\hline Experiência com a ferramenta & 25 & 8 & 21 & 11 & 23 & 88 \\
\hline Facilidade de uso percebida & 16 & 23 & 29 & 32 & 32 & 132 \\
\hline Funcionalidade da ferramenta & 50 & 27 & 68 & 42 & 33 & 220 \\
\hline Intenção de usar a TI & 11 & 3 & 16 & 5 & 9 & 44 \\
\hline Uso Atual & 104 & 66 & 128 & 60 & 38 & 396 \\
\hline Utilidade percebida & 11 & 12 & 19 & 48 & 42 & 132 \\
\hline \multicolumn{7}{|l|}{ Grupo\% } \\
\hline Características da tarefa & $28 \%$ & $18 \%$ & $35 \%$ & $10 \%$ & $8 \%$ & \\
\hline Experiência com a ferramenta & $28 \%$ & $9 \%$ & $24 \%$ & $13 \%$ & $26 \%$ & \\
\hline Facilidade de uso percebida & $12 \%$ & $17 \%$ & $22 \%$ & $24 \%$ & $24 \%$ & \\
\hline Funcionalidade da ferramenta & $23 \%$ & $12 \%$ & $31 \%$ & $19 \%$ & $15 \%$ & \\
\hline Intenção de usar a TI & $25 \%$ & $7 \%$ & $36 \%$ & $11 \%$ & $20 \%$ & \\
\hline Uso Atual & $26 \%$ & $17 \%$ & $32 \%$ & $15 \%$ & $10 \%$ & \\
\hline Utilidade percebida & $8 \%$ & $9 \%$ & $14 \%$ & $36 \%$ & $32 \%$ & \\
\hline
\end{tabular}

Tabela 4.4. Visão das percentagens de aplicações e das notas atribuídas às respostas dos parâmetros TAM e TTF Instituição Beta - EMPREGADOS -, Brasília - D.F., 2010

Fonte: Elaborado pelo autor (2010) 
A primeira dimensão observada foi a da "característica da tarefa" que aborda a habilidade de ajuste de tecnologia-tarefa do modelo TTF. Nessa dimensão estão inseridas as habilidades de customização de saídas. Observa-se que os empregados situaram-se, em sua maioria (82\%) nos níveis entre 1 e 3 da escala, sugerindo dificuldade em executar alterações de, por exemplo, relatórios de maneira geral. A falta de treinamento pode ser uma explicação a situação apresentada, já que o sistema tinha menos de um ano de implantação definitiva, ou mesmo pela facilidade de execução do modelo anterior (Figura 4.4.1).

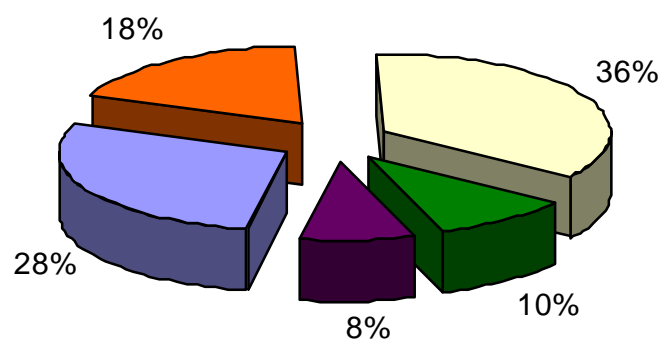

$\square$ 1) Nunca $\square$ 2) Raramente $\square$ 3) Às Vezes $\square$ 4) Geralmente $\square$ 5) Sempre

Figura 4.4.1. Percentagens de Característica da tarefa - Empregados Fonte: Elaborado pelo autor (2010)

Na observação da dimensão "experiência com a ferramenta", parâmetro de TTF, são avaliados os parâmetros como, por exemplo, acesso e entendimento do novo sistema. Os resultados demonstram que os empregados estão divididos entre insatisfeitos (38\%) localizados entre os níveis 1 e 2 da escala, e satisfeitos (39\%), localizados entre os níveis 4 e 5 da escala. Ainda existem mais $24 \%$ no ponto central da escala (Figura 4.4.2). 


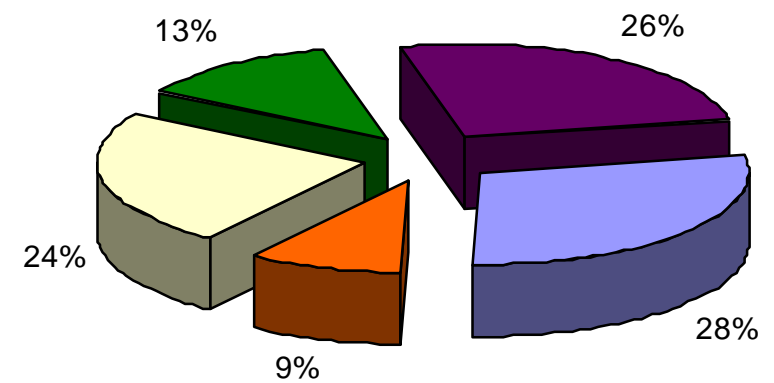

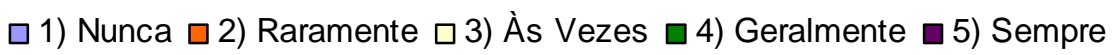

\section{Figura 4.4.2. PERCENTAgens de EXPERIÊNCIA COM A FERRAMENTA - EMPREgados -} Fonte: Elaborado pelo autor (2010)

Na dimensão "facilidade de uso percebida", parâmetro de aceitação da tecnologia, foram considerados itens como, por exemplo, facilidade de navegação para acesso à informação. Observa-se que os empregados demonstraram mais satisfação (48\% entre os níveis 4 e 5 ) que insatisfação ( $30 \%$ entre os níveis 1 e 2), tendo ainda $22 \%$ no nível 3 (Figura 4.4.3).

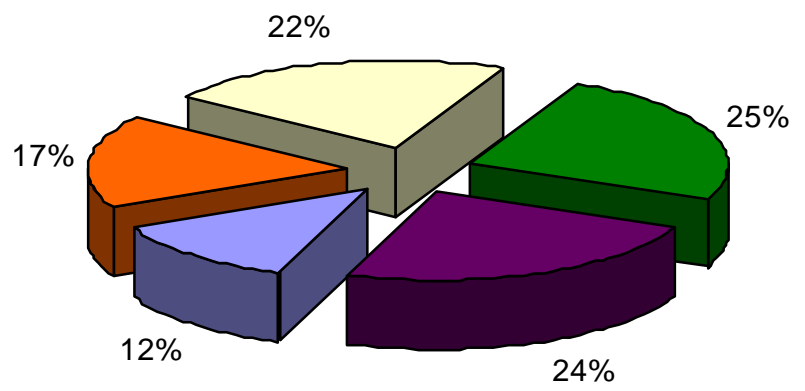

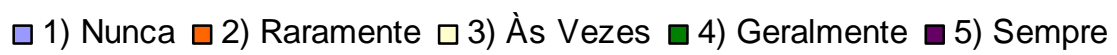

Figura 4.4.3. Percentagens de FaCiLIDAde de uSO PERCEBIDA - EMPREgados Fonte: Elaborado pelo autor (2010)

$\mathrm{Na}$ dimensão "funcionalidade da ferramenta", parâmetro de ajuste de tecnologia tarefa, são abarcados itens como, por exemplo, alcance a detalhes e 
pesquisas setoriais específicas. Verifica-se que os empregados dividem-se entre satisfeitos (34\%), tendo escolhido os níveis 4 e 5, e insatisfeitos (35\%), tendo escolhido os níveis 1 e 2, mas o maior percentual localiza-se na célula central, mostrando equilíbrio nesse critério (Figura 4.4.4).

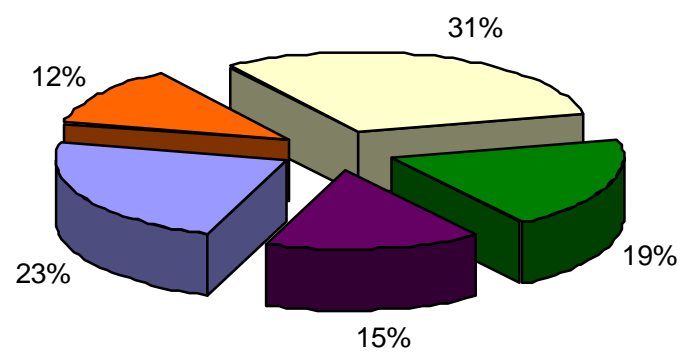

$\square$ 1) Nunca $\square$ 2) Raramente $\square$ 3) Às Vezes $\square$ 4) Geralmente $\square$ 5) Sempre

Figura 4.4.4. PERCENTAgenS de FunCIONALIDAdE DA FERRAMENTA - EMPREgAdos Fonte: Elaborado pelo autor (2010)

$\mathrm{Na}$ dimensão "intenção de uso da tecnologia", parâmetro do modelo de aceitação de tecnologia, são englobados os itens de confiabilidade do sistema, item de forte valor na tomada de decisão. Verifica-se que os empregados apresentaram tendência central de comportamento, estando 36\% deles situados no nível 3, sendo essa a maior representatividade quando considerados nos outros quatro parâmetros. Entre os satisfeitos, situados entre os níveis 4 e 5, encontram-se $32 \%$ dos empregados, e entre os insatisfeitos, ou seja, entre os níveis 1 e 2, é identificado, praticamente, o mesmo percentual. Esse resultado indica que o novo sistema ainda não apresenta a confiabilidade consolidada (Figura 4.4.5). 


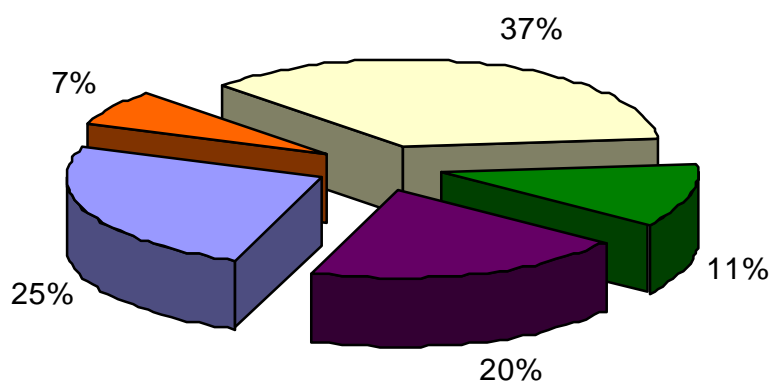

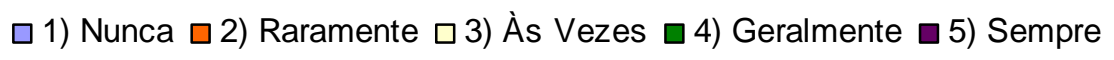

Figura 4.4.5. Percentagens de INTENÇão de USAR A TI - EMPREgados -

Fonte: Elaborado pelo autor (2010)

Na dimensão "uso atual", parâmetro do modelo de aceitação de tecnologia, são avaliados itens de uso rotineiro, como, por exemplo, acesso a relatórios. Observa-se que $75 \%$ dos empregados encontram-se nos níveis de 1 a 3 , demonstrando insatisfação com as funções, corroborando o que aponta o parâmetro de funcionalidade da ferramenta. Entre os satisfeitos, situados entre os níveis 4 e 5, encontram-se apenas $25 \%$ dos empregados, e entre os insatisfeitos, ou seja, entre os níveis 1 e 2, estão cerca de $43 \%$ do total. Depreende-se que o novo sistema ainda não é explorado de maneira adequada (Figura 4.4.6).

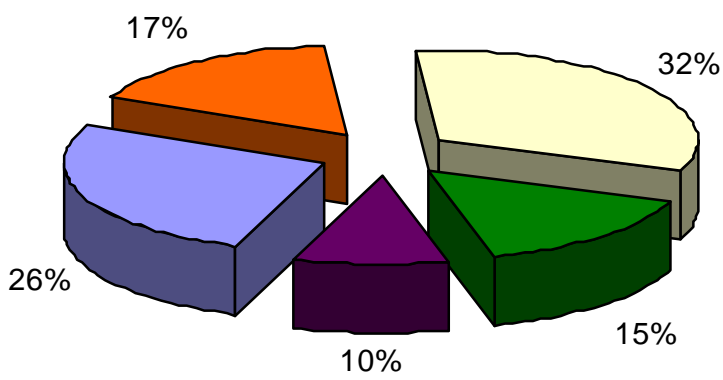

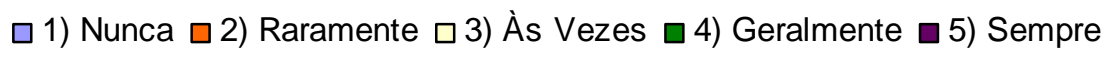


$\mathrm{Na}$ observação da dimensão "utilidade percebida", parâmetro de TTF, consideram-se parâmetros como, por exemplo, atendimento de expectativas e usabilidade das informações. Esse parâmetro reforça a percepção da potencialidade da ferramenta, pois $68 \%$ dos empregados consideraram-se satisfeitos, situando-se entre os níveis 4 e 5 da escala. Depreende-se que, apesar da satisfação apontada em outras dimensões, ainda existe enorme potencial a ser alcançado pela ferramenta (Figura 4.4.7).

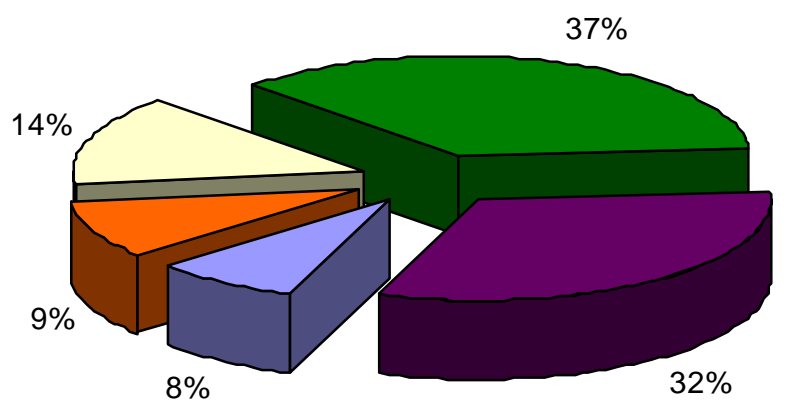

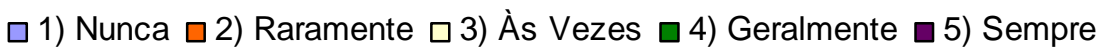

Figura 4.4.7. PERCENTAGENS DE UTILIDADE PERCEBIDA - EMPREgAdOS Fonte: Elaborado pelo autor (2010)

\subsection{Análise das Contribuições dos Usuários do Sistema sob a Ótica das dimensões}

Em outra forma de análise, as questões do relatório foram organizadas em 4 grupos, quais sejam: a) Intranet e Sistemas; b) Relatórios específicos; c) Relatórios financeiros e; d) Relatórios gerenciais.

A tabela 4.5 apresenta as percentagens de aplicações e das notas atribuídas às respostas dos elementos do sistema de apoio a decisão, na visão das dimensões. 


\begin{tabular}{|c|c|c|c|c|c|c|}
\hline Elementos do SAD / Descrição do item & $\begin{array}{l}\text { Discordo } \\
\text { Totalmente }\end{array}$ & $\begin{array}{c}\text { Discordo } \\
\text { Parcialmente }\end{array}$ & Indeciso & $\begin{array}{c}\text { Concordo } \\
\text { Parcialmente }\end{array}$ & $\begin{array}{l}\text { Concordo } \\
\text { Totalmente }\end{array}$ & $\begin{array}{l}\text { Nota } \\
\text { Média }\end{array}$ \\
\hline
\end{tabular}

Intranet e Sistema
As informações da Intranet do

Clube são úteis a mim

Conheço e tenho acesso à Intranet do Clube

O sistema do clube atende as minhas

necessidades de informações gerenciais

Os dados disponibilizados, via WEB,

pelo Clube, me são úteis

Retiro da Intranet as informações de

que preciso para desempenhar a minha função

$\begin{array}{ll}2 \% & 5 \% \\ 3 \% & 2 \% \\ 1 \% & 9 \% \\ 2 \% & 4 \% \\ 1 \% & 8 \%\end{array}$

$\begin{array}{llcc}8 \% & 29 \% & 57 \% & 78 \\ 6 \% & 20 \% & 69 \% & 81 \\ 17 \% & 51 \% & 21 \% & 70 \\ 9 \% & 39 \% & 46 \% & 78 \\ 21 \% & 37 \% & 32 \% & 71 \\ & & \text { Média Geral } & 75\end{array}$

Relatórios Específicos

Conheço as séries históricas de despesas do Clube

$11 \% \quad 21 \%$

$25 \%$

$26 \%$

$16 \%$

50

Conheço as séries históricas de receitas do Clube

Consigo com facilidade pesquisar informações

específicas sobre as despesas do Clube

Consigo com facilidade pesquisar informações

específicas sobre as despesas do meu setor

$13 \%$

$23 \%$

$18 \%$

$32 \%$

52

Consigo facilmente os detalhes de

despesas que necessito

Consigo facilmente os detalhes de

receitas que necessito

É fácil alterar um relatório específico de

despesas do meu setor

É fácil alterar um relatório específico

de receitas do meu setor

Tomo decisões baseadas nos números

gerados pelo sistema

\section{Relatórios Financeiros}

Acesso, periodicamente, os relatórios financeiros

Recebo, periodicamente, relatórios com as despesas c Recebo, periodicamente, relatórios com as despesas do meu Setor

Recebo, periodicamente, relatórios com as receitas do Clube

Recebo, periodicamente, relatórios com as receitas do meu Setor
$15 \%$

$13 \%$

$$
11 \%
$$

$13 \%$

$13 \%$

$13 \%$

$15 \%$

$14 \%$

$15 \%$

$44 \%$

$36 \%$

$31 \%$

$40 \%$

$32 \%$

$\begin{array}{ll}5 \% & 19 \% \\ 6 \% & 16 \% \\ 12 \% & 13 \% \\ 13 \% & 8 \% \\ 11 \% & 18 \% \\ 3 \% & 14 \%\end{array}$

$24 \%$

$20 \%$

$39 \%$

$34 \%$

$25 \%$

$15 \%$
$22 \%$

$21 \%$

$26 \%$

$33 \%$

$22 \%$

Média Geral

$34 \%$

$22 \%$

$16 \%$

$30 \%$

$25 \%$

$34 \%$ 1 0 8 1

5

execução orçamentária do meu Setor

Recebo, periodicamente,
gerenciais do meu Setor

Tenho facilidade de acesso a

informações que necessito

$3 \%$

$14 \%$

\begin{tabular}{rr}
$17 \%$ & 57 \\
$36 \%$ & 60 \\
$20 \%$ & 50 \\
$16 \%$ & 52 \\
$22 \%$ & 52 \\
$35 \%$ & 66 \\
\hline dia Geral & 56
\end{tabular}

Tabela 4.5. Descrição geral das percentagens de aplicações e das notas atribuídas às respos tas dos elementos do Sistema de Apoio a Decisão (SAD) Instituição Beta, Brasília - D.F., 2010 Fonte: Elaborado pelo autor (2010) 
Com relação ao elemento "Intranet e Sistema", observa-se forte concordância, tanto pelos valores percentuais de aplicação, quanto pela média geral (75 pontos). Os resultados sugerem que, apesar do conhecimento e acesso à Intranet do Clube, as notas mais baixas referem-se ao atendimento de necessidades de informações gerenciais para o desempenho da função (TURBAN et al., 2009).

O item que trata de "Relatórios Específicos" apresenta tendência central, com maioria dos percentuais de resposta concentrados na atitude "indeciso", sendo que as notas mais baixas atribuídas identificam dificuldade de interagir com 0 sistema de forma a alterar relatórios específicos (ad hoc). A nota mais alta do grupo (56) sugere tomada de decisões baseada nos números gerados pelo sistema, porém, o percentual dominante, 38\% caracteriza a maneira tradicional como os antigos administradores decidiam, baseados no seu "feeling" (TURBAN et al., 2009).

A pior média geral entre os elementos de SAD avaliados foi com relação aos "Relatórios Financeiros", sugerindo indecisão e discordância, o que leva a crer que os usuários do sistema tanto não acessam, quanto não recebem os relatórios financeiros. Possíveis motivos para este fato podem ser a falta de rotina na distribuição dos relatórios, ou mesmo a falta de interesse dos usuários. (DRUCKER, 2006).

A análise do item "Relatórios Gerenciais" ratifica a facilidade de acesso às informações que foi atribuída ao elemento "Intranet e Sistema" (nota média = 66). Entretanto, a média geral indica concordância parcial com relação ao recebimento dos relatórios, o que também é compatível com o que foi encontrado no elemento "Relatórios Financeiros". 


\section{CONCLUSÕES E RECOMENDAÇÕES}

O objetivo geral desse trabalho foi o de verificar como soluções de tecnologia da informação auxiliam no processo de tomada de decisão em uma instituição da capital federal. Foram feitas análises em documentos, entrevistas com os principais gestores, visitas e conversas informais e aplicação de instrumento de pesquisa na forma de questionário em escala Likert, para melhor entender a adoção do sistema de apoio à decisão. Foram estudados os fluxos operacionais e processos setoriais na execução de coletas, tratamento, análise e disseminação da informação.

A formulação do questionário utilizado nos estudo, teve como base as variáveis ou dimensões descritas pelos modelos TTF, dos autores Goodhue e Thompson, e TAM, do autor Davis. Eles avaliam o nível de utilidade e aceitação dos sistemas, na visão de seus usuários.

A pesquisa teve como foco a relação entre processo decisório e sistemas de apoio a decisão, bem como a identificação das ferramentas de soluções de tecnologia da informação, exposição dos benefícios da utilização de sistemas de tecnologia da informação para apoio à tomada de decisão e a aplicabilidade dos conceitos Business Intelligence e Data Warehouse no processo de tomada de decisão, buscando alcançar os objetivos específicos do trabalho.

Para o primeiro objetivo específico relativo à descrição da relação entre processo decisório e sistemas de apoio a decisão na instituição, observou-se que o uso da ferramenta de tecnologia da informação ainda está aquém do esperado, principalmente pela falta de treinamento, fato identificado em conversas informais e nas visitas setoriais realizadas. No entanto, e em conformidade com o descrito na literatura, identificou-se o grande potencial de utilização do sistema de apoio à decisão na função de disponibilizar informações de nível gerencial, auxiliando a alta direção na gestão da instituição. Um aspecto identificado que vale destacar é o da resistência à mudança apresentado pela maioria dos empregados dos setores envolvidos. Quebrar a inércia e apego a procedimentos e rotinas realizadas por anos seguidos é tarefa bastante difícil para o administrador e deve ter o envolvimento e comprometimento dos gestores setoriais. Se o projeto não for bem 
aceito por todos, os novos procedimentos tenderão a cair no esquecimento ou, pior ainda, ser mal falado, levando a presidência a crer que fez a escolha errada em adotar as mudanças propostas. Nesse aspecto, durante a implantação do sistema, é aconselhável realizar exaustivos treinamentos para que os empregados sintam que os novos procedimentos, além de propiciar um grande ganho de tempo, são bastante confiáveis e que podem substituir o antigo facilmente. Uma falha nesse processo pode resultar em perda do investimento realizado.

Quanto ao segundo objetivo específico, referente à identificação das ferramentas de soluções de tecnologia da informação utilizadas pela instituição Beta, observou-se que o sistema adotado é um banco de dados, ao mesmo tempo simples e robusto, que tem a capacidade de gerenciamento de dados e informações. As funções têm acesso rápido, proporcionando o cruzamento de dados, com boa disponibilização de consultas, pesquisas e relatórios, acompanhamento do orçamento e atingimento de metas, possibilitando escolhas de alternativas de ação para cenários específicos.

No terceiro objetivo específico, que trata de Business Intelligence com utilização de Data Warehouse no processo de tomada de decisão verificou-se a capacidade de utilização das ferramentas como apoio às tomadas de decisão, já que os usuários do sistema são capazes de construir consultas, combinar informações de fazer pesquisas. Todavia permanece o uso ainda incipiente do sistema, principalmente pelo vício de utilização de procedimentos anteriores, dificuldades intrínsecas à informática e falta de treinamento específico. Para o sucesso de um projeto é sumamente importante a criação e manutenção de um clima de cooperação e harmonia entre os setores afetados que fornecerão os dados que comporão o Data Warehouse. A vasta experiência adquirida anteriormente pelos empregados mais antigos será fonte importante de inteligência para extração dos dados ocultos e não identificados na situação anterior à implantação das ferramentas de SAD.

Em relação ao quarto objetivo, que discorre sobre os benefícios da utilização de sistemas de tecnologia da informação para apoio à tomada de decisão da instituição, verificou-se resultados satisfatórios em muitos quesitos, assim como descrito na literatura, como, por exemplo, identificação de problemas, acompanhamento de desempenho, atingimento de metas, visualização rápida de 
informações importantes antes desprezadas e melhor controle orçamentário. Porém, as dificuldades sobrevieram na correta utilização do sistema.

Uma limitação vivenciada para a realização da pesquisa foi a impossibilidade de observação de todos os participantes em suas áreas de trabalho, principalmente, por conflito entre os horário de trabalho da instituição e do pesquisador. Um segundo fator de limitação foi a distância física entre os departamentos da instituição que chegam a distar 1 quilometro entre si, dificultando a observação de mais de um setor por turno de trabalho.

Quanto aos aspectos negativos, destacou-se a grande dependência de softwares da Microsoft que devem ser instalados em todos os setores envolvidos e conflitos entre as versões dos programas. Além desse, percebe-se que não foram realizados testes e validações de maneira exaustiva nos dados carregados no Data Warehouse.

O sucesso da implementação de um Sistema de Apoio a Decisão depende de um projeto muito bem estruturado que identifique os dados mais importantes da organização e suas fontes. Uma falha nessa identificação fará com que o projeto apresente problemas de qualidade, segurança e credibilidade, caindo em descrédito imediato.

Sugere-se, para estudos futuros, nova pesquisa acerca do assunto para verificar a evolução da utilização das ferramentas abordando, especialmente, o treinamento dos usuários, bem como aceitação e utilização da nova tecnologia. 


\section{REFERÊNCIAS}

BISPO, C. A. F.; CAZARINI, E. W. A nova geração de sistemas de apoio à decisão. In: ENEGEP, 18, 1998, Niterói, Rio de Janeiro, Brasil. Anais... Niterói: ABEPRO, 1998.

DRUCKER, PF. A administração na próxima sociedade. Nobel, São Paulo, SP, 2002. p $13-65$.

DRUCKER, PF. A decisão eficaz in Processo decisório: Os melhores artigos da Harvard Business Review. Elsevier, Rio de Janeiro, RJ, 2006. p 9 - 26.

FERAUCHE, TMY. Teoria geral de sistemas e informação. Centro Paula Souza, Faculdade de Tecnologia da Praia Grande, 2006. 56 p.

FORTULAN, MR; GONCALVES F, EDUARDO V. Uma proposta de aplicação de business intelligence no chão-de-fábrica. Gest. Prod., São Carlos, v. 12, n. 1, Apr. 2005. Available from

$<$ http://www.scielo.br/scielo.php?script=sci_arttext\&pid=S0104-

530X2005000100006\&lng=en\&nrm=iso >. access on 19 June 2010. doi:

10.1590/S0104-530X2005000100006.

GIL, AC. Como elaborar projetos de pesquisa. 4 ed. São Paulo: Atlas, São Paulo, SP, 2002.

GOLFARELLI ,MATTEO ; RIZZI, STEFANO , CELLA, IURIS. Beyond data warehousing: what's next in business intelligence? Proceedings of the 7th ACM international workshop on Data Warehousing and OLAP, November 1213, 2004, Washington, DC, USA [doi>10.1145/1031763.1031765]

HADDAD R. Access 2000 \& VBA. Érica, São Paulo, SP, 2000. 378 p.

INMON, WH. Como construir o Data Warehouse. Campus, Rio de Janeiro, RJ, 1997. $381 \mathrm{p}$.

KOTLER P. Administração de marketing. Prentice Hall, São Paulo, SP, 2000. p $121-150$.

LAUDON, KC. Sistemas de informações gerenciais. Pearson Prentice Hall, São Paulo, SP, 2007. 451p.

LAPPONI, JC. Estatística usando Excel. Regressão linear simples. Laponni treinamento e editora, SP, 2000. p 379 - 414.

LÖBLER, ML; VISENTINI, MS; VIEIRA, KM. A Aceitação do Comércio Eletrônico Explicada pelos Modelos TAM e TTF Combinados. $30^{\circ}$ encontro da ANPAD, 2006, Salvador, Brasil. Disponível em: 
http://www.ufsm.br/adm/mestrado/Enanpad/enanpad2006-adib-1406.pdf. Acesso em 21/11/2010

MATIAS-PEREIRA, J; Metodologia Científica. Fundação Universidade de Brasília, DF, 2007.

MINAYO, MCS; $O$ desafio do conhecimento: pesquisa qualitativa em saúde. 4.ed. São Paulo/Rio de Janeiro: HUCITEC/ABRASCO, 1996.

O'BRIEN, J. Administração de sistemas de informação: uma introdução. 13. ed, McGraw-Hill, São Paulo, SP, 2007.

PEREIRA MJLB.; FONSECA JGM. Faces da decisão: as mudanças de paradigmas e o poder da decisão. Makron Books, São Paulo, SP, 1997.

REZENDE, Y. Informação para negócios: os novos agentes do conhecimento e a gestão do capital intelectual. Ci. Inf., Brasília, v. 31, n. 1, Jan. 2002. Available from <http://www.scielo.br/scielo.php?script=sci_arttext\&pid=S010019652002000100008\&lng=en\&nrm=iso >. access on 19 June 2010. doi: $10.1590 /$ S0100-19652002000100008

REGINATO, L; NASCIMENTO, AM. Um estudo de caso envolvendo Business Intelligence como instrumento de apoio à controladoria. Rev. contab. finanç., São Paulo, v. 18, n. spe, June 2007. Available from <http://www.scielo.br/scielo.php?script=sci_arttext\&pid=S151970772007000300007\&lng=en\&nrm=iso $>$. access on 19 June 2010. doi: $10.1590 / \mathrm{S} 1519-70772007000300007$.

SHIMIZU, T; Decisão nas organizações. 2. ed, Atlas, São Paulo, SP, 2006. 419 p.

TURBAN E.; SHARDA, R.; ARONSON, JE.; KING, D.; Business Intelligence, um enfoque gerencial para a inteligência do negócio. Bookman, Porto Alegre, RS, 2009.

WELLIANDRE, JCA; ANDRADE, DF;VASCONCELOS, AP; ARAÚJO,AMS; BATISTA, MJ. Análise do número de categorias da escala de Likert aplicada à gestão pela qualidade total através da teoria da resposta ao item. XXIII Encontro Nac. de Eng. de Produção - Ouro Preto, MG, Brasil, 21 a 24 de out de 2003. ENEGEP 2003 ABEPRO. Disponível em: http://www.abepro.org.br/biblioteca/ENEGEP2003_TR0201_0741.pdf. Acesso em 17/10/2010.

YIN, RK.; Estudo de caso: planejamento e métodos. Bookman, Porto Alegre, RS, 2010.

ZANELLA, ICH. Metodologia da Pesquisa. Secretaria de Educação a Distância, SEAD/UFSC, Florianópolis, SC, 2006. 
ANEXOS 


\section{Anexo A - Organograma da Empresa Beta}

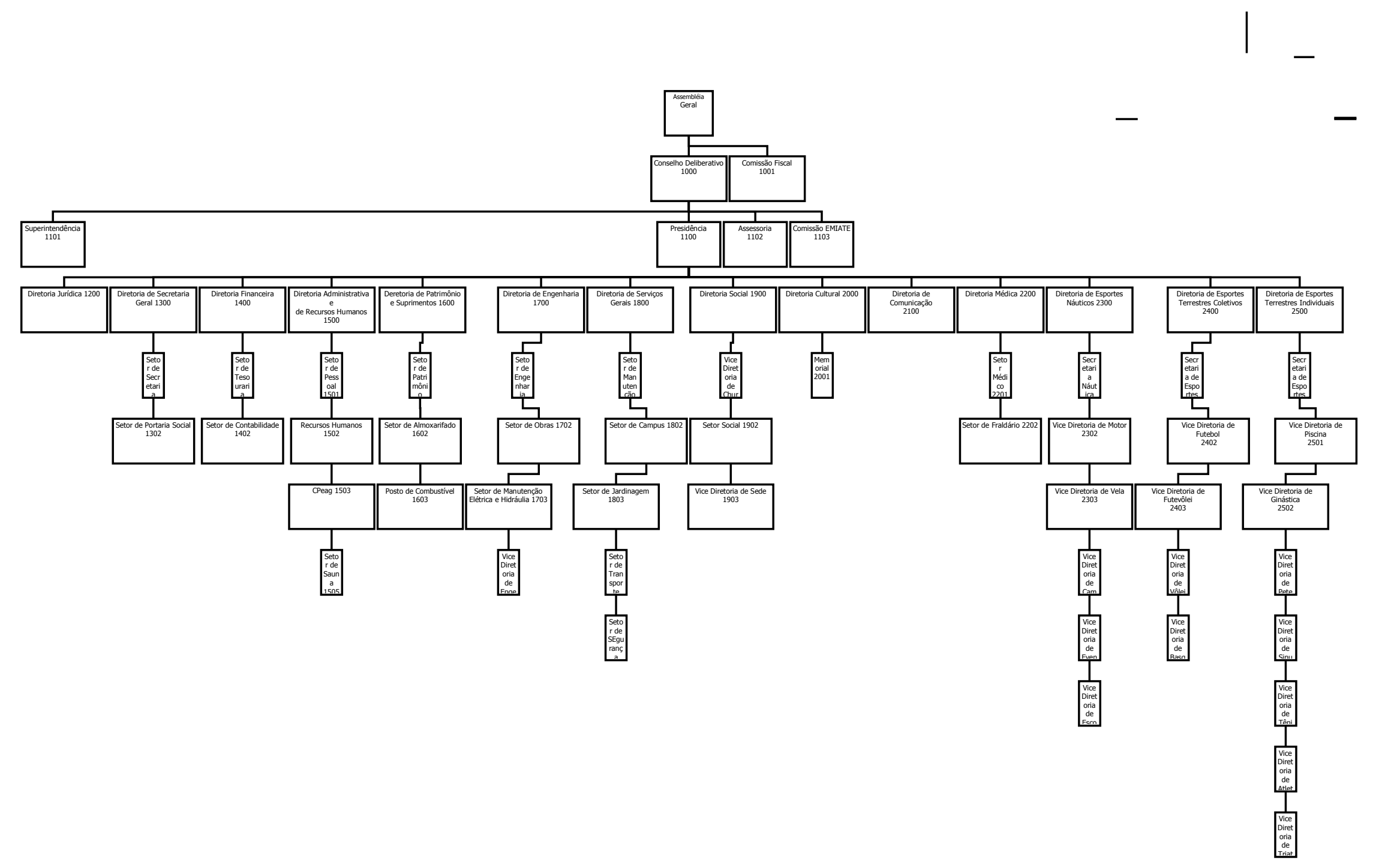




\section{APÊNDICES}




\section{Apêndice A - Pesquisa Quantitativa}

\section{Questionário para avaliação do Sistema de Apoio à Decisão}

\section{Informações do Cargo:}

Presidência

Diretoria

Funcionalismo

\section{1 - Discordo Totalmente \\ 2 - Discordo Parcialmente \\ 3 - Indeciso \\ 4 - Concordo Parcialmente \\ 5- Concordo Totalmente}

1) Conheço e tenho acesso à Intranet do Clube

2) As informações da Intranet do Clube me são úteis
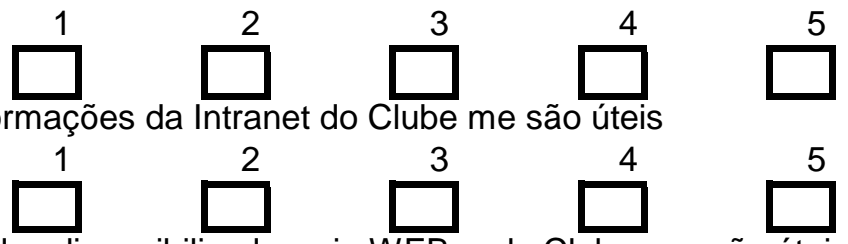

3) Os dados disponibilizados, via WEB, pelo Clube, me são úteis

4) O sistema do clube atende as minhas necessidades de informações gerenciais

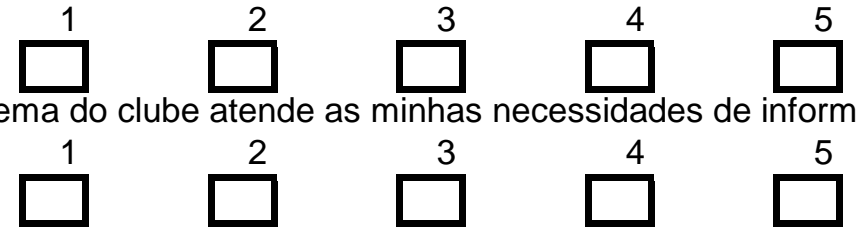

5) Retiro da Intranet as informações de que preciso para desempenhar a minha função

6) Acesso, periodicamente, os relatórios financeiros
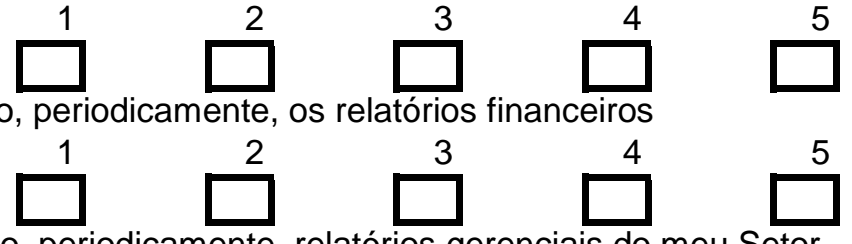

7) Recebo, periodicamente, relatórios gerenciais do meu Setor

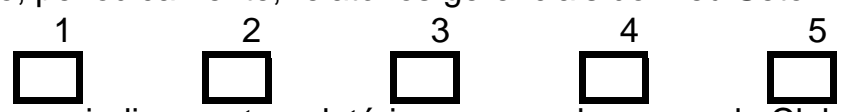

8) Recebo, periodicamente, relatórios com as despesas do Clube

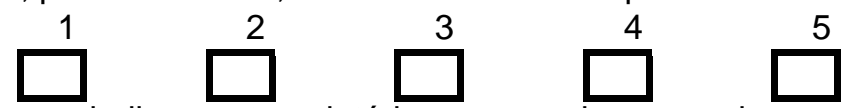

9) Recebo, periodicamente, relatórios com as despesas do meu Setor

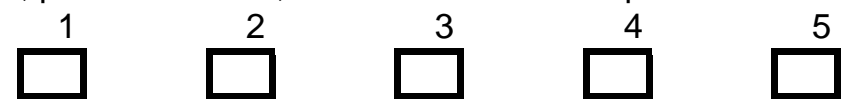


10) Recebo, periodicamente, relatórios com as receitas do Clube

11) Recebo, periodicamente, relatórios com as receitas do meu Setor
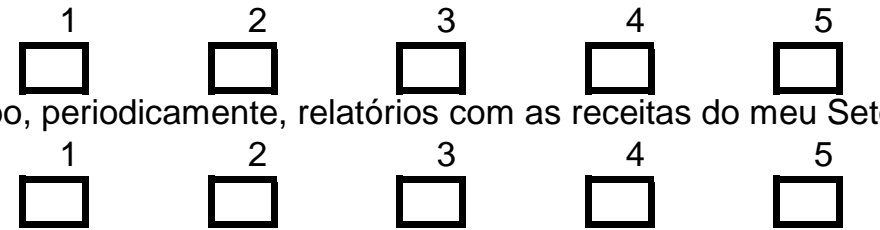

12) Recebo, periodicamente, relatórios da execução orçamentária do Clube

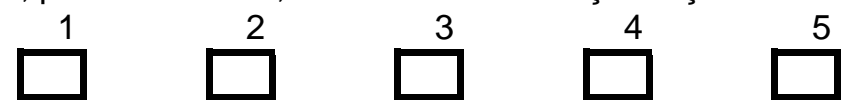

13) Recebo, periodicamente, relatórios da execução orçamentária do meu Setor

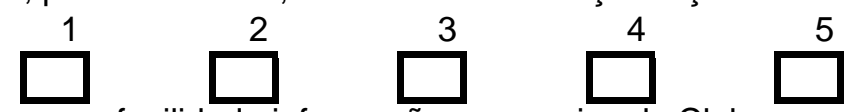

14) Consigo com facilidade informações gerencias do Clube

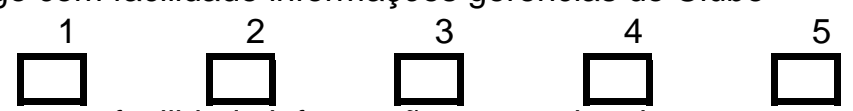

15) Consigo com facilidade informações gerencias do meu setor

16) Tenho facilidade de acesso a informações que necessito

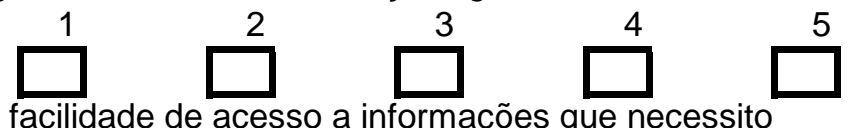

17) É fácil alterar um relatório específico de despesas do meu setor

18) É fácil alterar um relatório específico de receitas do meu setor
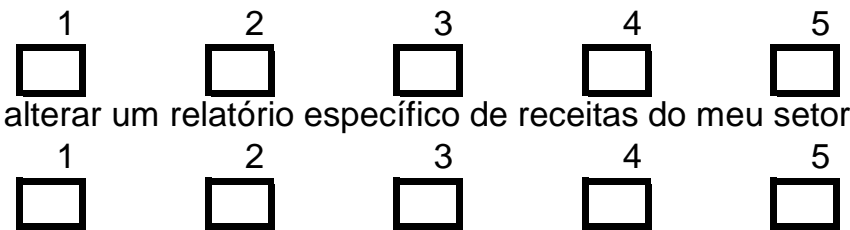

19) Consigo com facilidade pesquisar informações específicas sobre as despesas do Clube

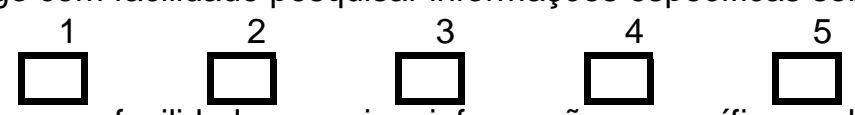

20) Consigo com facilidade pesquisar informações específicas sobre as despesas do meu setor

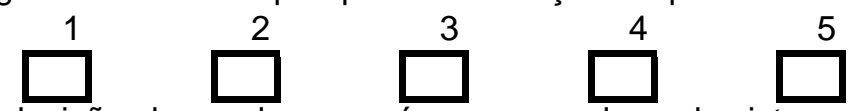

21) Tomo decisões baseadas nos números gerados pelo sistema

22) Consigo facilmente os detalhes de despesas que necessito
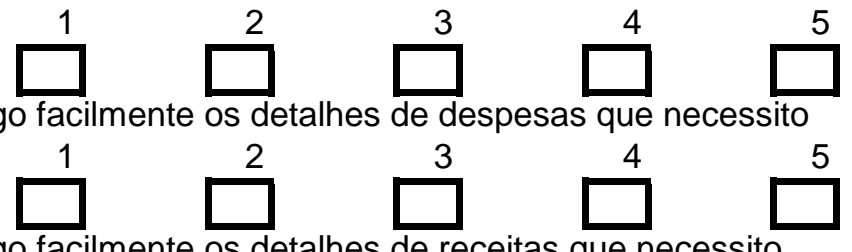

23) Consigo facilmente os detalhes de receitas que necessito

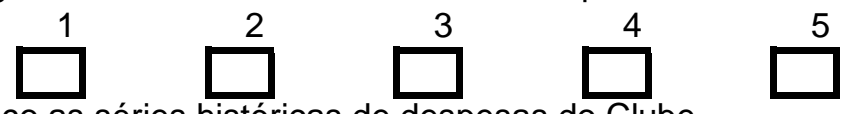

24) Conheço as séries históricas de despesas do Clube

25) Conheço as séries históricas de receitas do Clube
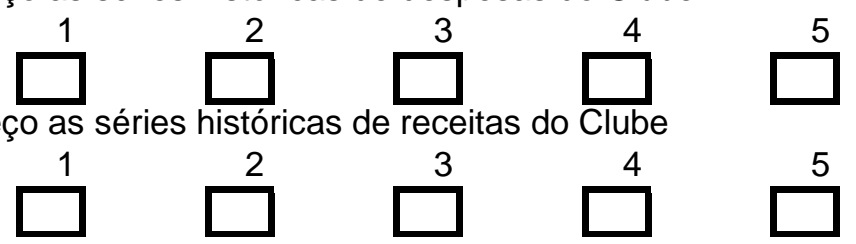